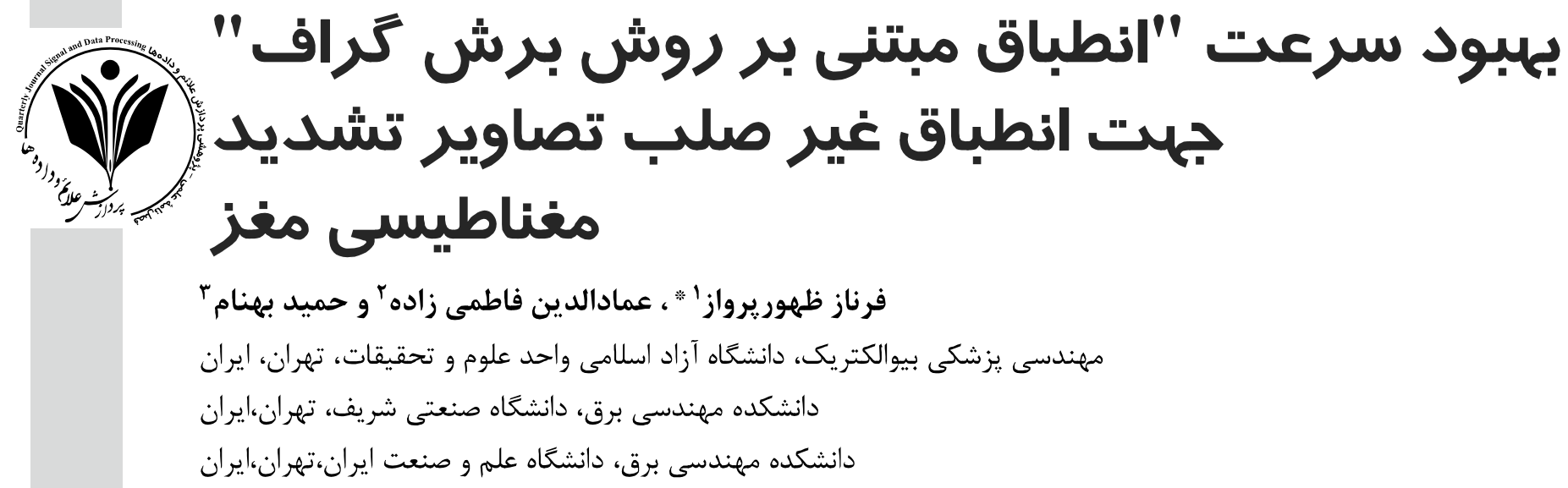

جكيده

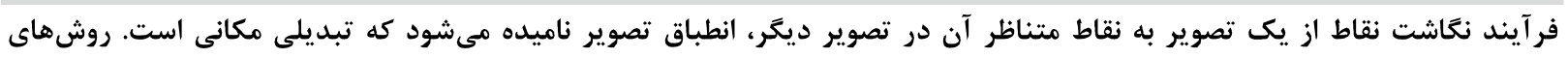

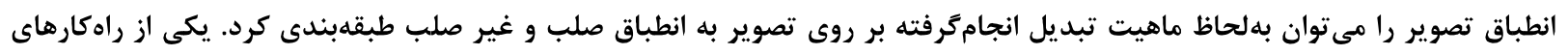

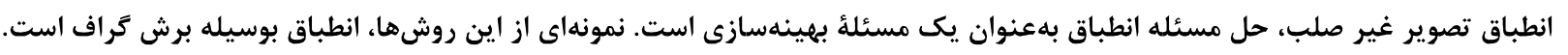

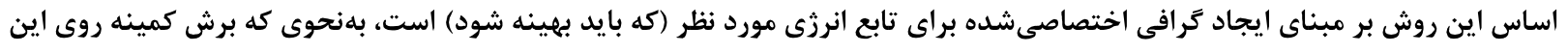

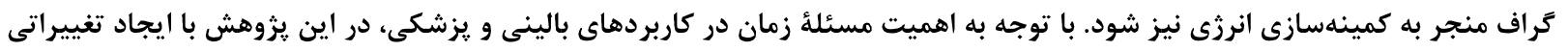

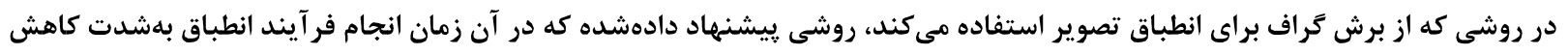

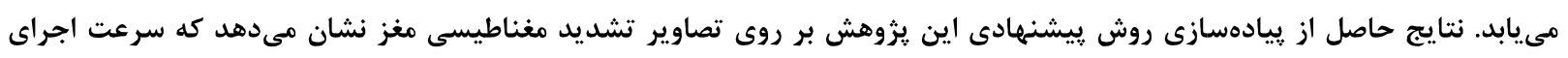

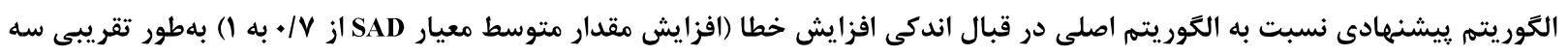
برابر مىشود.

وازَّان كليدى: انطباق تصوير غير صلب، برش كراف، تصوير تشديد مغناطيسى

\title{
Speed improvement in graph-cuts-based registration for non-rigid image registration of brain magnetic resonance images.
}

\author{
Farnaz ZohourParvaz $^{* 1}$, Emad Fatemizadeh ${ }^{2}$ \& Hamid Behnam ${ }^{3}$ \\ Biomedical Engineering, Islamic Azad University, Science and Research \\ Branch of Tehran, Iran \\ Electrical Engineering, Sharif University of Technology, Tehran, Iran \\ Electrical Engineering, Iran University of Science and Technology, \\ Tehran, Iran
}

\begin{abstract}
Image processing methods, which can visualize objects inside the human body, are of special interests. In clinical diagnosis using medical images, integration of useful data from separate images is often desired. The images have to be geometrically aligned for better observation. The procedure of mapping points from the reference image to corresponding points in the floating image is called Image Registration. It is a spatial transform. These images might be different because they were taken at different times or applied by using different devices. By the nature of this image transformation, image registration can be classified into rigid registration and non-rigid registration. The freedom's degree in a rigid transformation is relatively low and the methods of rigid image registration are becoming mature. In contrast, non-rigid image registration is
\end{abstract}


still a challenging problem because of its high degree of freedom. One of the non-rigid image registration methods is turning the registration problem into an optimization problem and obtaining the optimal value as the result of registration. An example of these methods is the graph-cuts based registration. The basic technique is to construct a specialized graph for the energy function to be minimized in a way that the minimum cut on this graph also minimizes the energy. Given that our focus in this research, is on the medical image registration, and time is one of the critical factors in medical applications. It seems that improvement of this method in terms of run time will be helpful for its clinical and medical applications. In order to achieve this goal, in this research, with modifying the energy function, we proposed a method that significantly reduces the run time of registration process. The implementation results of our proposed method on the images with artificial deformations which are similar to the most pessimistic possible deformation modes in real image data, show that the proposed algorithm is about three times faster than the existing algorithm, while the average amount of SAD criterion will be increased from 0.7 to 1 .

Keywords: Non-rigid image registration, Graph-cuts, Magnetic resonance images

(1)، بررسى درمان، مقايسه دادهاى بيمار با اطلسهاى

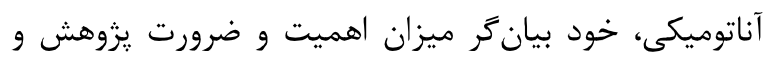
مطالعات بيشتر در اين حوزه از يردازش تصوير است. شورد

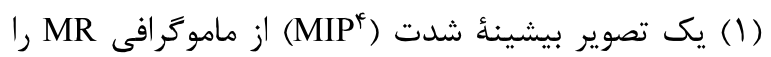
بدون انطباق (سمت جِ) و با انطباق (سمت راست) نشان

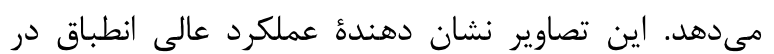
شناسايى ضايعات سرطانى است [1].
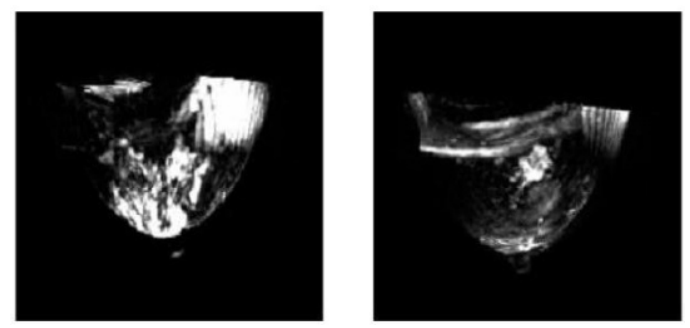

[1] MR Mكل -1): كاربرد انطباق تصوير در مامو مافر

(Figure-1): Registration of MR mammography images

انطباق تصوير را مىتوان بهلحاظ ماهيت تبديلى كه

بر روى تصوير انجام مى انطباق تصوير غير صلب \& طبقهبندى كرد. تبديل صلب شامل

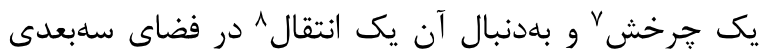
است [2]. بهطور كلى به ساير روشهاى انطباق تصوير به غير از روشهاى انطباق تصوير صلب، انطباق تصوير غير صلب بل بهوري اطلاق مىشود. در تبديل صلب فقط جرخش و انتقال مجاز است؛ بنابراين روشهاى انطباق صلب بهدليل محدوديتى كه

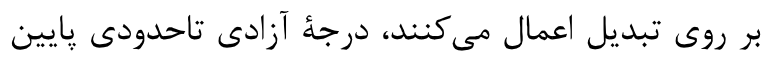
داشته و روشهاى انطباق تصوير صلب بهطور تقريبى به نبدي

${ }^{4}$ Maximum Intensity Projection

${ }^{5}$ Rigid image registration

${ }^{6}$ Non-rigid image registration

${ }^{7}$ Rotation

${ }^{8}$ Translation

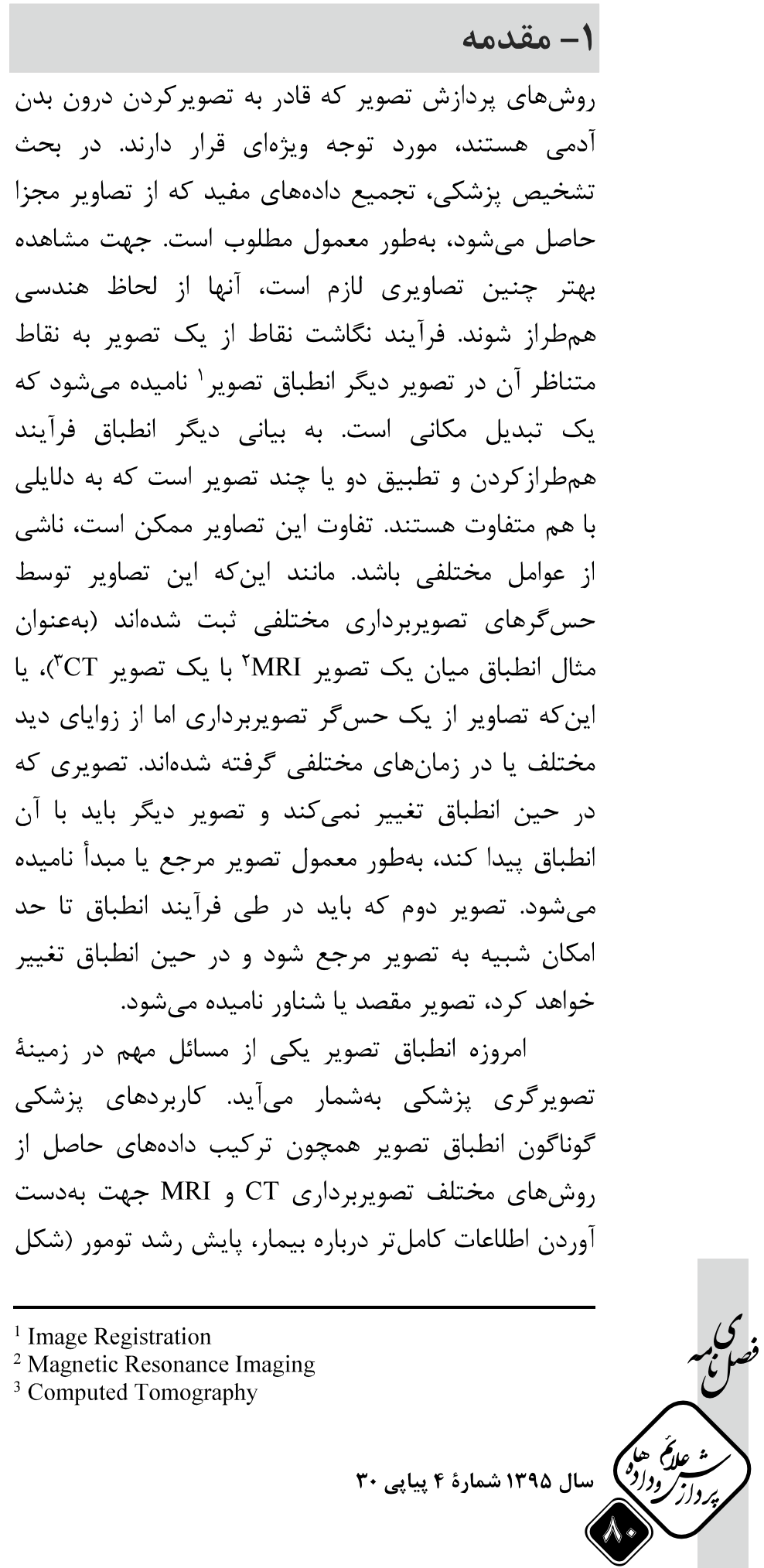


ييشنهاد مى كنيم كه كاهش جشمَيرى در زمان انجام انطباق بهوسيله برش كراف ايجاد مىكند. در بخش عال به ديه ارائه نتايج حاصل از روش ويشنهادى و مقايسه آن با نتايج

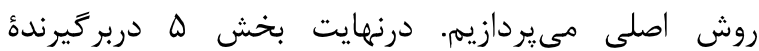
نتيجه گيرى و جمعبندى كلى اين يزوهش است. همجنين بيشنهادهايى كه به نظر مىرسد براى انجام مطالعات و ولني

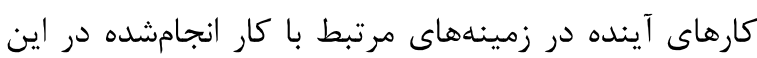
يزوهش مفيد واقع شود، مطرح شده است.

\section{ץ- مسئله انطباق تصوير بــهـ روش بــرش كر اف} r-1 - اصول مسئله انطباق تصوير عمل انطباق تصوير معادل با پِيداكردن تناظر مكانى ميان دو تصوير I و J است. اين كار بهطور معمول با بيداكردن تبديل

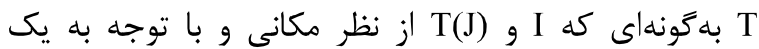
معيار عدم تشابه تصوير به تصوير C(I,T(J) منطبق شوند،

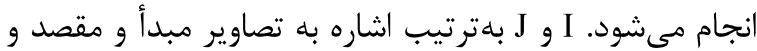

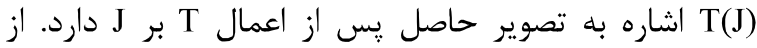
طرفى للزم است كه T با افزودن يك تابع S(T) جهت جريمه هايى كه غير واقعى هستند، تنظيم شود. بنابراين از نظر رياضى مىتوان مسئله انطباق را يافتن تبديل بهينه تعريف كرد به كونهاى كه: $\mathrm{T}^{*}=\arg \min _{\mathrm{T}} \mathrm{C}(\mathrm{I}, \mathrm{T}(\mathrm{J}))+\lambda \mathrm{S}(\mathrm{T})$.

كه در آن ג ثابت مثبتى است كه ميزان جريمه را براى

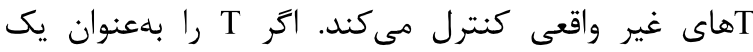

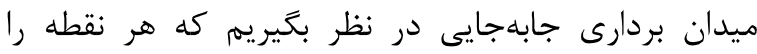

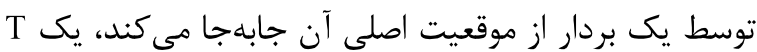
غير واقعى بلهور معمول به معنى يك ميدان بردارى جابهجايى ناهموار است. بنابراين S اغلب تابع هموارى خوانده مىشود. بلطور معمول درعمل از مجموع دامنههاى مشتقات مختلف

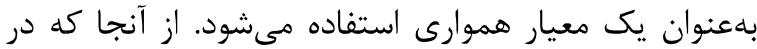

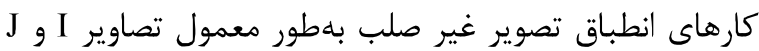
توسط يك روش تصويربردارى يكسان گرفته مىشوند،

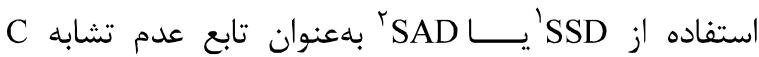

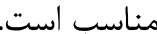

\footnotetext{
${ }^{1}$ Sum of Squared Difference
}

${ }^{2}$ Sum of Absolute Differences
اشباع رسيدهاند؛ اما مسئلة انطباق تصوير غير صلب بهخاطر درجه آزادى بسيار بالاى آن و نياز ذاتى به هموارى، همجنان إنان

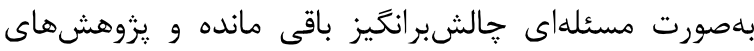
بيثتر و كاملتر در اين حوزه بهدليل كاربردهاى مفيد و

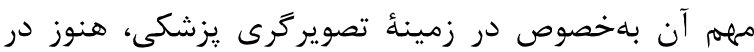
حال انجام است. جهت مرورى كلى بر روشهاى انهای انطباق تصوير غير صلب به [ץ] رجوع كنيد. يكى از راهكارهاى انطباق غير صلب تصاوير، تبديل

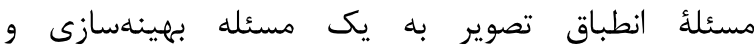
بهدستآوردن مقدار بهينه اين مسئله بهعنوان نتيجه حاصل بله بله

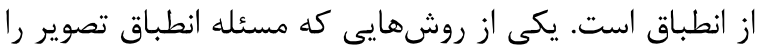

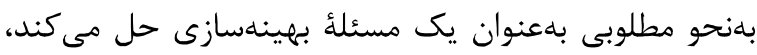

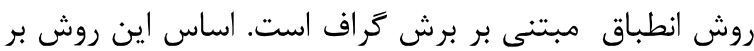
مبناى ايجاد يك گراف اختصاصىشده براى تابع انرزى مورد نظر (كه بايد بهينه شود) است، بهنحوى كه برش كمينه روى كراف منجر به كمينهسازى انرزى (سراسرى يا محلى) نيز

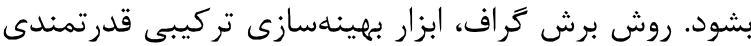

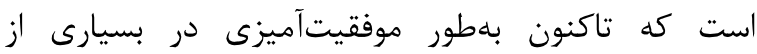
زمينههاى يردازش تصوير همجون بازيابى تصوير، استريو و حركت، سنتز تصوير، ناحيهبندى تصوير و همجنين در تصويرگرى يزشكى [7]-[4] مورد استفاده قرار گرفته است؛ اما استفاده از آن بهمنظور انطباق تصوير، به سالهاى اخير آنير برمى برش تراف در حل مسئله انطباق تصوير روش كارآمدترى نسبت به برخى روشهاى نوآورانه كه بهطور كستردماف جهت انطباق تصاوير غير صلب استفاده مىشوند، مى باشد. در اين يزوهش ما با ايجاد يك سرى تغييرات در الكوريتمى كه از برش كراف براى انطباق تصاوير دوبعدى إنى

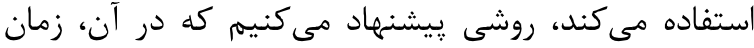
انجام فرآيند انطباق نسبت به روش اصلى بهشدت كاهش بـان

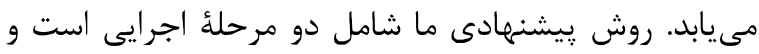

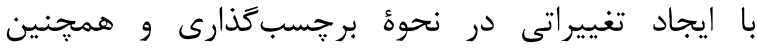
قراردادن يك مقدار آستانه براى تابع انرزى مورد نظر، بادئ درنهايت باعث مىشود فرآيند كمينهسازى انرزى و بلهدنبال آن انطباق تصوير در قبال اندكى افزايش خطا (كه قابل جشميوشى است) با سرعت بيشترى انجام گيرد.

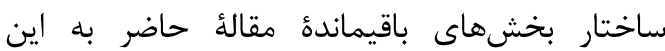
صورت است: در بخش ץ به نحوء فرمولبندى مسئله انطباق باق

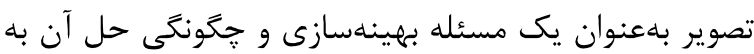
روش برش كراف خواهيم يرداخت؛ سبس در بخش ؟ روشى 
تصاوير بهطور معمول به شكل گَسته ثبت مىشوند. با

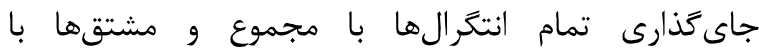

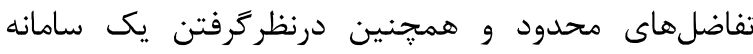
همسايكى N جهار اتصالى در فضاى دوبعدى دمدي، درنهايت بلهورت زير حاصل خواهد شد:

$D^{*}=\arg \min _{D} E_{F}(D)$

for $E_{f}(D)=\sum_{x=X}|I(x)-J(x+D(x))|$

$+\lambda \sum_{(x, y) \epsilon N}\|D(x)-D(y)\|$.

كه در آن (x,y) است، اتر و تنها اتر x و y ي إيكسلهاى

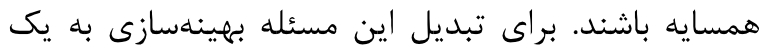
مسئله برجسب گذارى گسسته، مجموعه متناهى محدود شود. در اينجا مرحله دوم

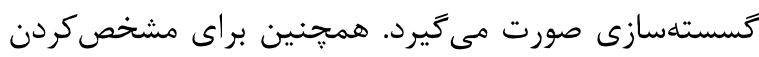

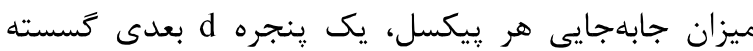

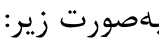

$W=\{0, \pm s, \pm 2 s, \ldots, \pm w s\}^{d}$

انتخاب مىشود؛ بهطورى كه D(x) E W. توجه داشته باشيد

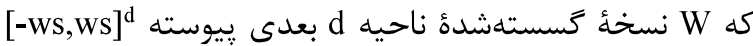

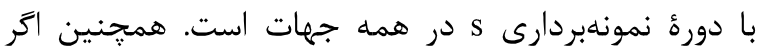
s<1 باشد، مىتوان جابةجايىهايى با واحد كمتر از ريكسل

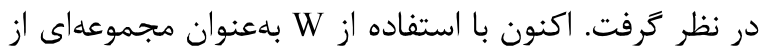
برجسبها كه هر D(x) مى Dواند به خود بخيرد، بهينهسازى

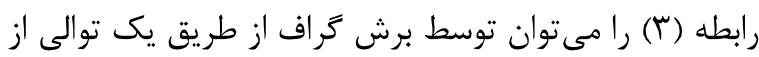
جابهجايىهاى گسترشى آلفا حل كرد. اين فرآيند

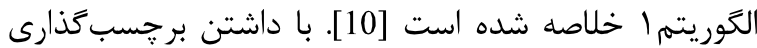

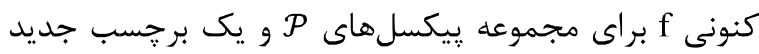

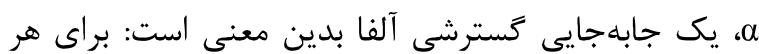

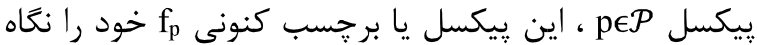
مى تغيير مىدهد. بنابراين يك جابهجايى گَسترشى آلفا يك

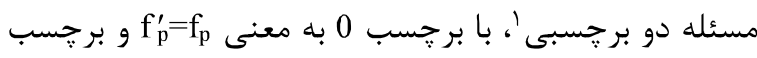

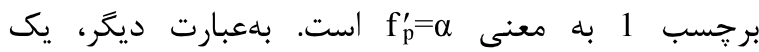
جابهجايى كسترشى d اجازه مى دهد كه هر مجموعهاى از

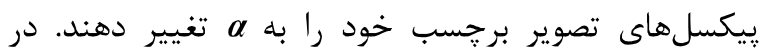
شكل (T) نمونهاي از يك جابجايى كسترشى آلفا نشان داده

${ }^{1}$ Two-label problem

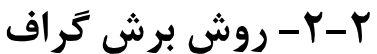

بلهوركلى روش برش تراف جهت حل مسائل

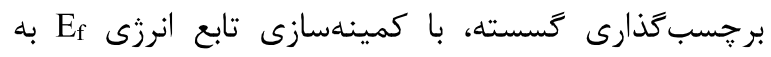
شكل استاندارد زير بهكار ميرود.

$E_{f}=\sum_{p \in \mathcal{P}} D_{p}\left(f_{p}\right)+\sum_{(p, q) \in N} V_{p, q}\left(f_{p}, f_{q}\right)$.

كه در آن P مجموعه يِكسلها و N يك سامانه همسايكى

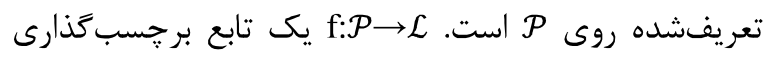

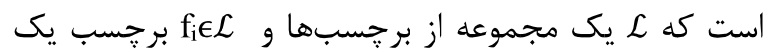

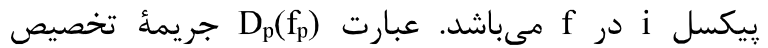
برجسب (f) به קֶيكسل p را اندازمخيرى كرده و عبارت جريمه تخصيص برجسبهاى $V_{p, q}\left(f_{p}, f_{q}\right)$

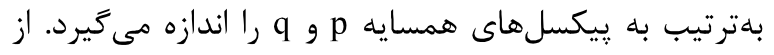
مجموع نخست بلهطور معمول بهعنوان مؤلفؤ داده ياد مىشود؛ جون مقدار آن بهطور معمول از داده مشاهدهده محاسبه مىشود. از مجموع دوم نيز اغلب بهعنوان مؤلفه

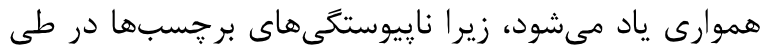

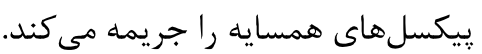

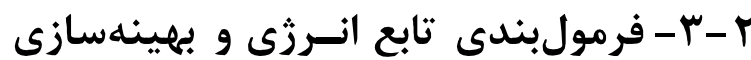 توسط برش كراف}

فرض كنيد I و لبهترتيب تصاوير مبدأ و مقصد با بعد d بوده

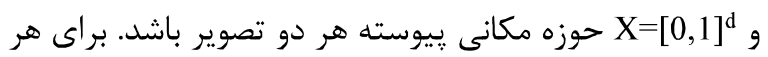
نقطئ مكانى I(x) ، x=(x)

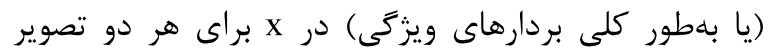

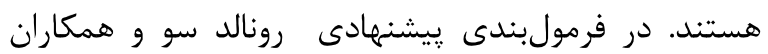

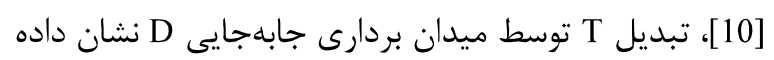

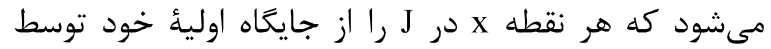
بردار D(x)eR به نقطه جديد بهطوركلى C در رابطه (1) مىتواند هر معيار عدم تشابه تصوير به تصويرى باشد. در اينجا C بهعنوان انتخرال معيار عدم تشابه نقطه به نقطه در حوزه كل تصوير در نظر كرفته مىشود. همجنين براى اين معيار، عدم تشابه نقطه به نقطه از قدر مطلق تفاضل يعنى |(I) - J(x) - J(x) استفاده مىشود كه در آن |. | ايراتور نرم L1 است. از مشتق نحست آنست

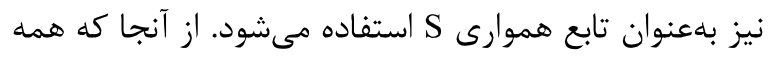

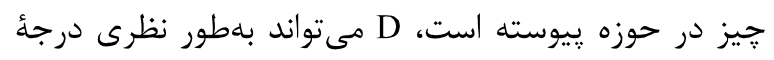
آزادى نامحدودى داشته باشد. در اينجا نخستين مرحله

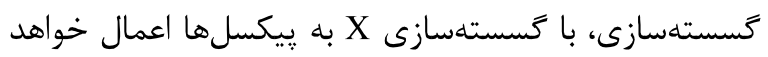
شد. گَستهسازى در اين مورد امرى طبيعى است، زيرا 
انطباق تصاوير غير صلب استفاده مىشوند: روش مبتنى بر

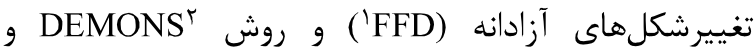
همجنين با روش ديكرى كه مسئله انطباق تصوير غير صلب

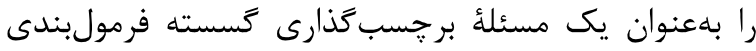
مى كند يعنى روش LP مان مقايسه كردند. اين مقايسه نشان داد كه روش بيشنهادى نسبت به سه روش دئن رئر در برابر موارد جالشبرانگيز مختلف انطباق غير صلب بسيار مقاومتر بوده و همجنين صحت انطباق بالاترى نسبت به سه روش

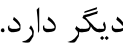

r- روش بيشنهادى جهـت انطبـاق غيـر صلب تصوير با برش گر اف ن.

در اين يزوهش ما ابتدا رنج تغيير شكل مختلف را بر روى

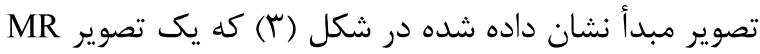

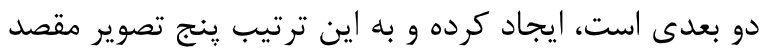

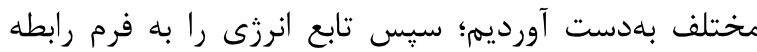
(r) تشكيل داده و پِ از آن بهينهسازى انرزى را توسط

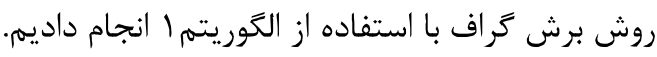
همانطور كه انتظار مىرفت با توجه به تصاوير حاصل يس از انطباق، صحت انطباق بسيار بالا و تصاوير خروجى

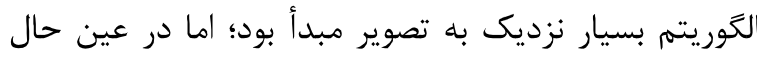

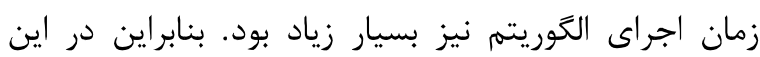

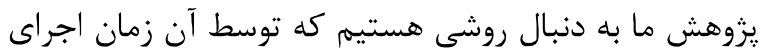
الكوريتم انطباق تصوير با برش كراف را كاهش دهيم. جهت رسيدن به اين هدف روشى پيشنهاد خواهيم داد كه

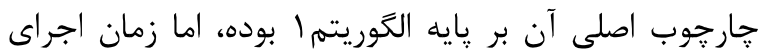

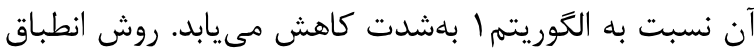

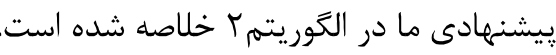

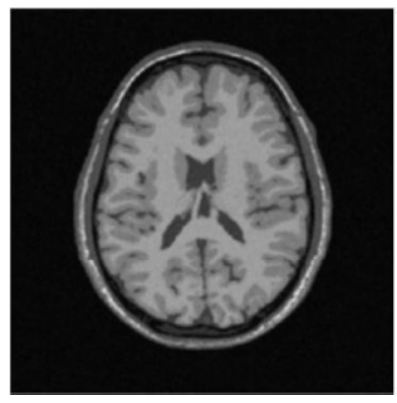

(شكل-r): تصوير مبدأ استفادهشده در ريادهسازى

(Figure-3): The source image used in the implementation

${ }^{1}$ Free-form deformations based method

${ }^{2}$ Demons based method

${ }^{3}$ Linear Programming
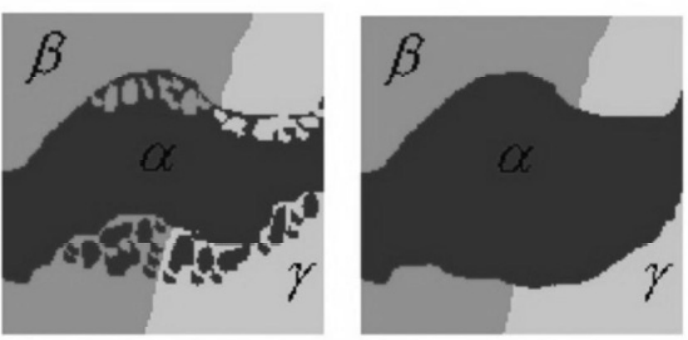

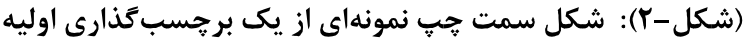

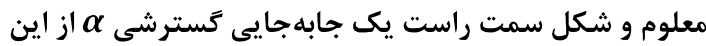
بر جسب كذارى اوليه را نشان مى دهد. يك جابهجايى كسترشى

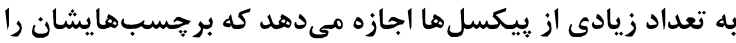
بلمطور همزمان تغيير دهند.

(Figure-2): The left figure shows an example of a given initial labeling, and the right figure shows an $\alpha$-expansion move of this initial labeling. An a-expansion move allows large number of pixels to change their labels simultaneously.

كولموكروف و زوبى [15] نشان دادند كه روش برش كراف

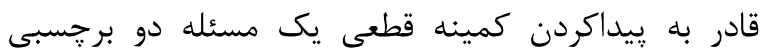

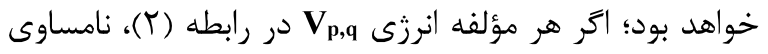
زير را ارضا كند:

$\mathrm{V}_{\mathrm{p}, \mathrm{q}}(0,0)+\mathrm{V}_{\mathrm{p}, \mathrm{q}}(1,1) \leq \mathrm{V}_{\mathrm{p}, \mathrm{q}}(0,1)+\mathrm{V}_{\mathrm{p}, \mathrm{q}}(1,0)$ مىتوان نشان داد كه هر جابهجايى گسترشى در فرمولبندى

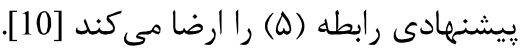
التوريتهم ورودى: شروع با يك ميدان بردارى جابهجايى D و يك تابع انرزى خروجى: يك ميدان بردارى جابهجايى بهينه أروى $\mathrm{D}^{*} \Leftarrow \mathrm{D} .1$ ז. به تعداد دفعات گسترش آلفا مرحله بـ را تكرار كن

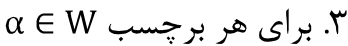

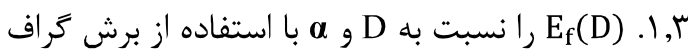

$$
\text { كمينه كن }
$$

$D^{*} \Leftarrow D$ L باشد آنغاه F رونالد سو و همكاران [10] با استفاده از الكوريتما انطباق غير صلب تصاوير تشديد مغناطيسى مغز را را انجام دادند. آنها نشان دادند كه فرآيند بهينهسازى با روش برش كريد بلهادگى در كمينه محلى كرفتار نشده و راه حل حاصل بران

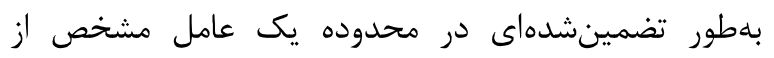

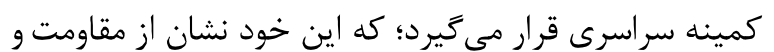

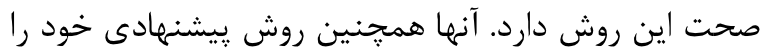

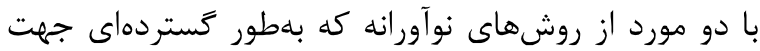




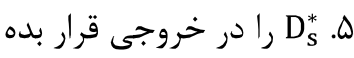

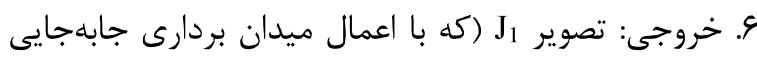

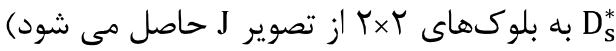

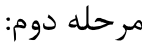

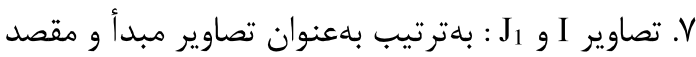
جديد A. با ميدان بردارى جابهجايى دلخواه D شروع كن

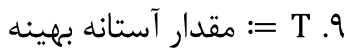

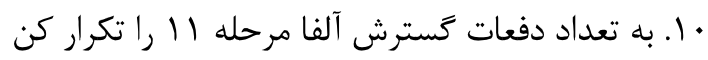
$\alpha \in W_{2}$ ll. براى هر برجس

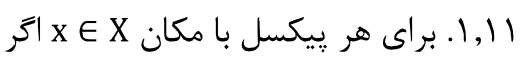

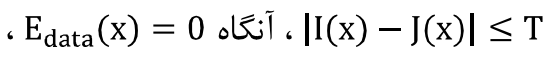
$\mathrm{E}_{\text {data }}(\mathrm{x})=|\mathrm{I}(\mathrm{x})-\mathrm{J}(\mathrm{x}+\mathrm{D}(\mathrm{x}))|$ درغير اين صورت $\mathrm{E}_{\text {data }}=\sum_{\mathrm{x}=\mathrm{X}} \mathrm{E}_{\text {data }}(\mathrm{x}) . \mathrm{r}, \mathrm{M}$ $\mathrm{E}_{\text {smooth }}=\lambda \sum_{(\mathrm{x}, \mathrm{y}) \in \mathrm{N}}\|\mathrm{D}(\mathrm{x})-\mathrm{D}(\mathrm{y})\| . r, \| 1$

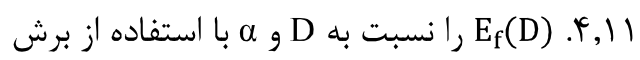
كراف كمينه كن $\mathrm{D}^{*} \Leftarrow \mathrm{D}$ باشد

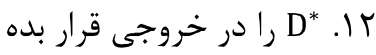

\section{مرحلهُ نخست الكَوريتم انطباق ييشنههادى}

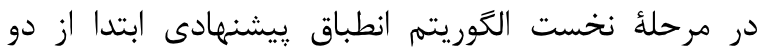

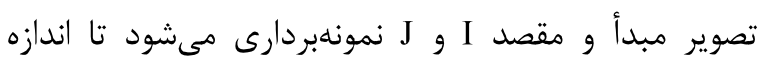
تصوير به يك جهارم كاهش يابد. تصويرهاى بهدست آمده از

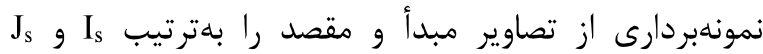

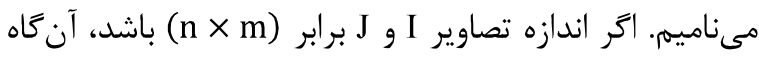
اندازه تصاوير IS Is

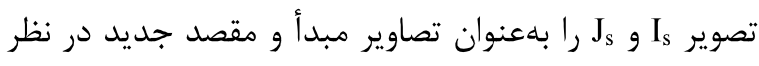

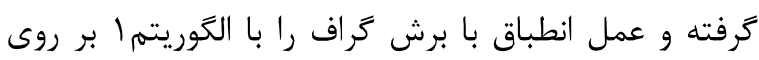
اين دو تصوير انجام مىدهيم. براى مشخصكردن ميزان

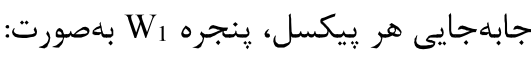
انتخاب مىشود؛ Whe $\mathrm{W}_{1}=\{0, \pm \mathrm{s}, \pm 2 \mathrm{~s}, \ldots, \pm \mathrm{ws}\}^{2}$ بهطورى كه D(x) موجود در رابطهُ (r) متعلق به اين رينجره است. برجسبهاى a درواقع بردارهاى جابهجايى هستند كه به شكل زوجمرتبهايى با استفاده از اعداد موجود در ينجره

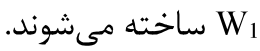
براى شروع ابتدا يك ميدان بردارى جابهجايى دلخواه

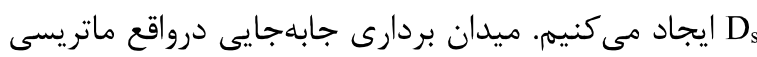

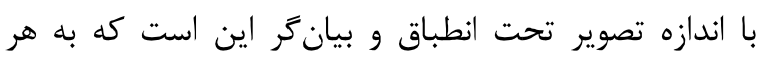

r-1- الكوريتهم انطباق بيشنههادى

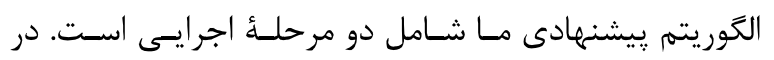

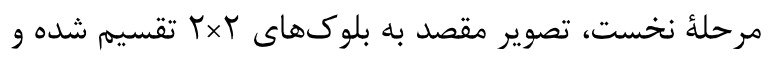

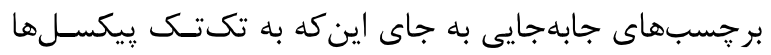

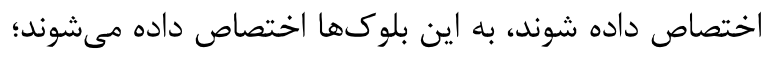

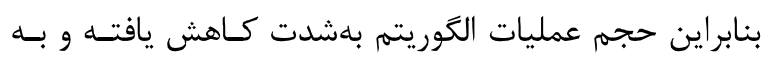
دنبال آن زمان اجراى اين الكوريتم بسيار كم خواهد شد.

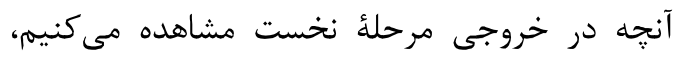

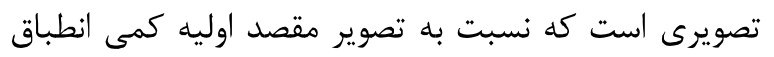

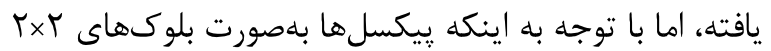

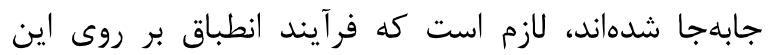

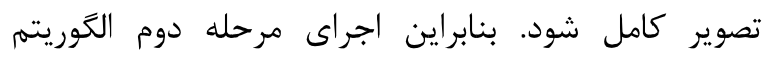

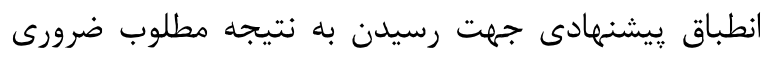

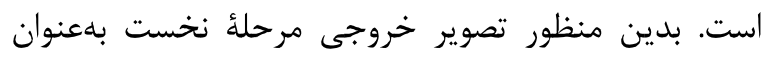
ورودى به مرحله دوم داده مىشود. در مرحله دوم، تصوير

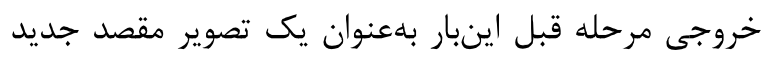

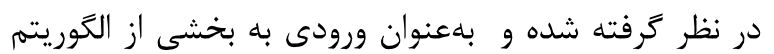

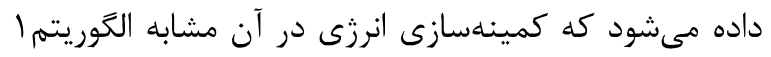

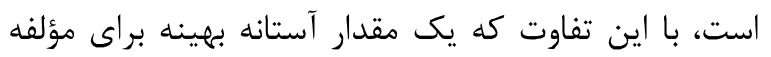

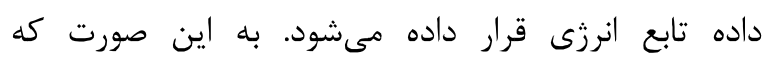

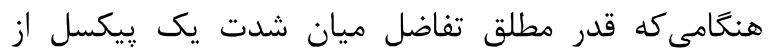

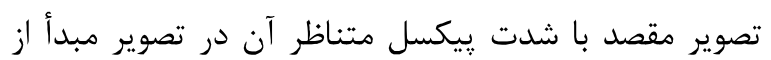

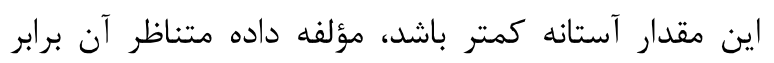

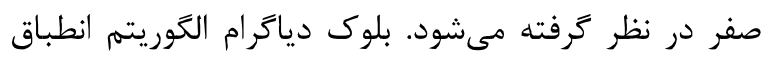

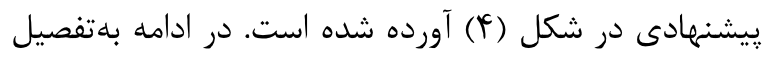
به جزئيات اين الكوريتم خواهيم يرداخت. الكوريتهمب

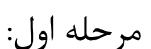

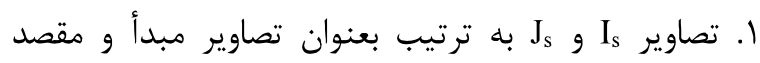
جديد با نمونهبردارى از تصاوير مبدأ و مقصد I و J J بهدست مى آيد Ds

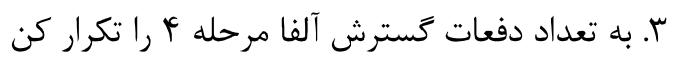
$\alpha \in W_{1}$ f. براى هر برجس

$$
\begin{aligned}
& \mathrm{E}_{\text {data }}=\sum_{\mathrm{x}=\mathrm{X}}\left|\mathrm{I}_{\mathrm{s}}(\mathrm{x})-\mathrm{J}_{\mathrm{s}}\left(\mathrm{x}+\mathrm{D}_{\mathrm{s}}(\mathrm{x})\right)\right| . \mathrm{l}, \mathrm{f} \\
& \mathrm{E}_{\text {smooth }}=\lambda \sum_{(\mathrm{x}, \mathrm{y}) \in \mathrm{N}}\left\|\mathrm{D}_{\mathrm{s}}(\mathrm{x})-\mathrm{D}_{\mathrm{s}}(\mathrm{y})\right\| ., \mathrm{r}, \mathrm{f} \\
& \text { f } \\
& \text { كراف كمينه كن } \\
& D_{s}^{*} \in D_{s} \text { باشد آن }
\end{aligned}
$$




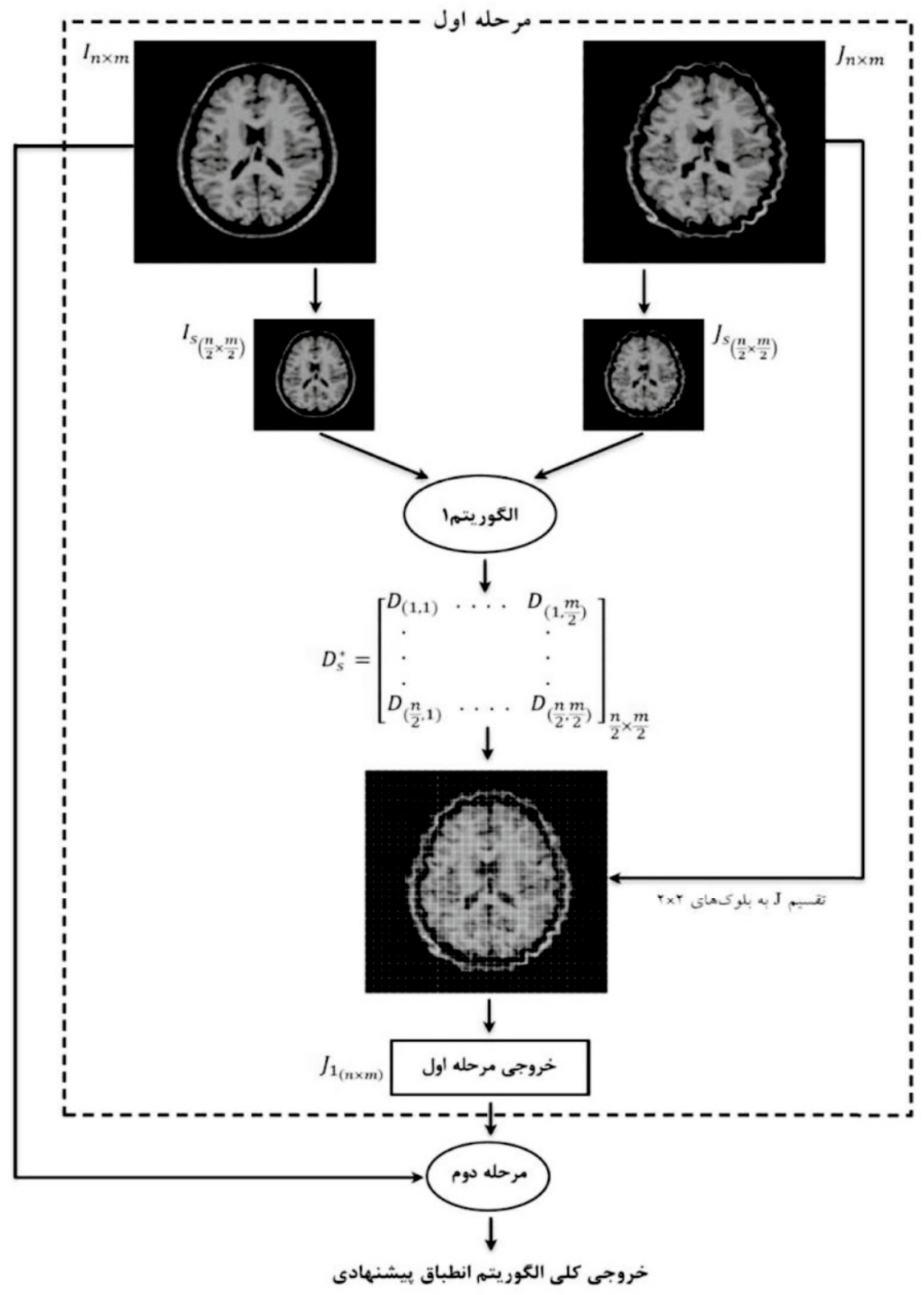

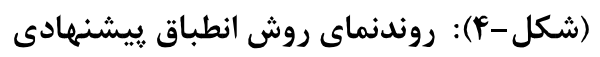

(Figure-4): Block diagram of the proposed registration method

تخصيص برجسب جديد d به پيكسل متناظر اين رأس و

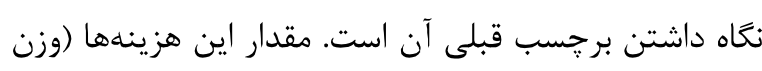

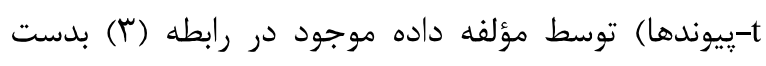

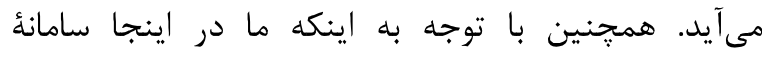

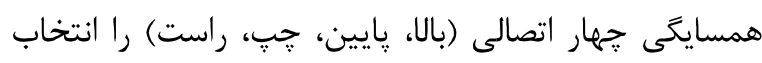

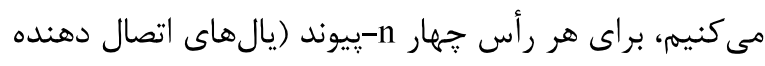

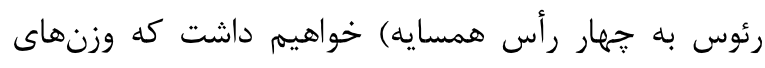

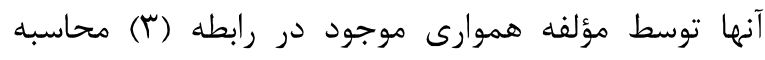

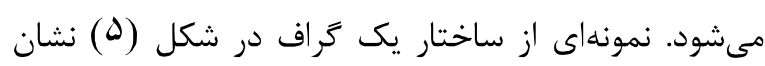

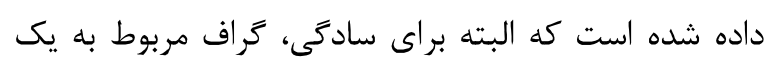
تصوير يكبعدى را نمايش مىدهد.
נِيكسل از تصوير مقصد جه برجسبى اختصاص داده مىشود.

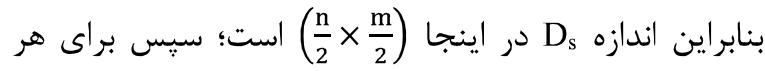

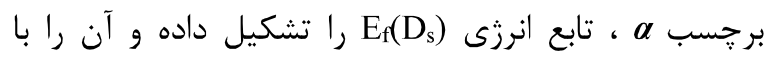

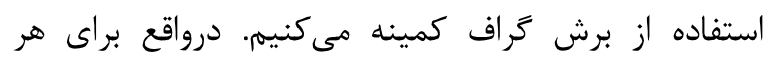

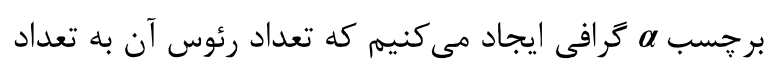

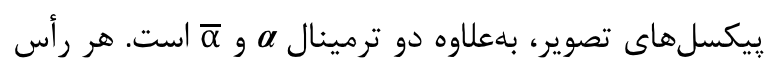

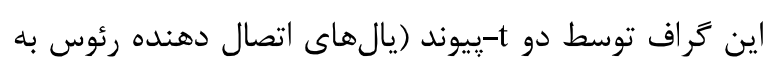

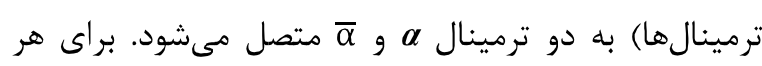

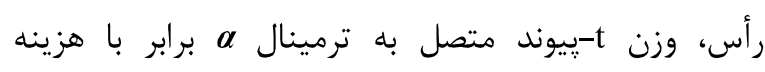

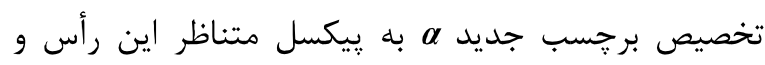
وزن t-t لينك متصل به ترمينال 


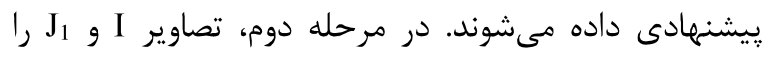

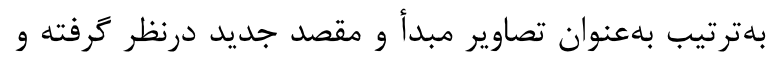
عمل انطباق را بر روى آنها انجام مىدهيم. عمل انطباقى كه

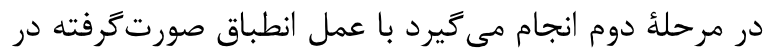

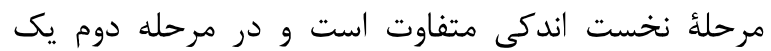

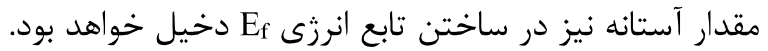

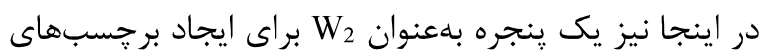
a براى شروع ابتدا يك ميدان بردارى جابهجايى دلخواه

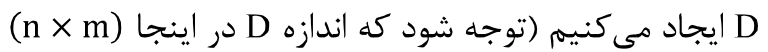

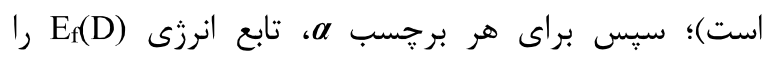
تشكيل داده و آن را با استفاده از برش كراف كراف كمينه

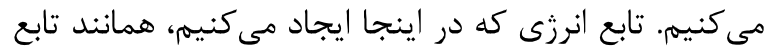

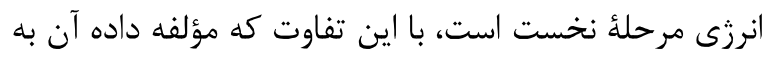

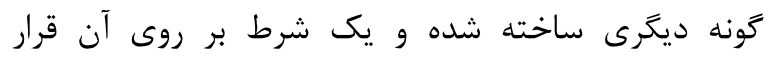
مىدهيم. بدين ترتيب كه اتر قدر مطلق تفاضل ميان شدت يك يِكسل از تصوير مقصد با شدت پيكسل متناظر آن در

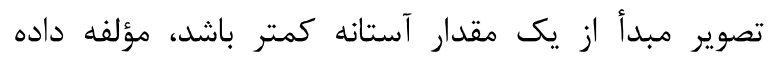

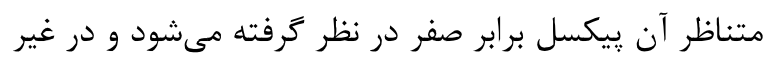

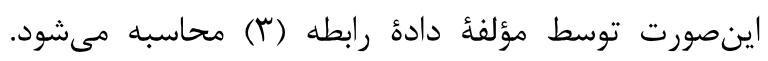
بنابراين براى آن دسته از ييكسلهاى متناظر در دو تصوير

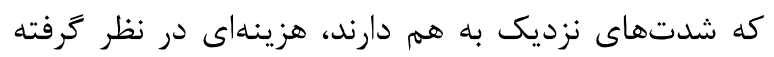

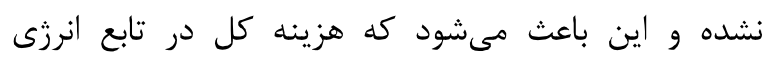

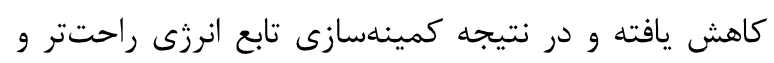
با سرعت بيشترى انجام گيرد. مؤلفه هموارى تابع انرزى نيز همانند مرحلة نخست و توسط مؤلفه هموارى رابطه (r) ايجاد مىشود. اكنون مىتوانيم كراف مورد نظر را به همان

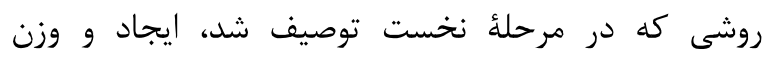
يالهاى آن را توسط مؤلفهاى داده و هموارى مشخص

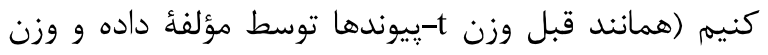

n- ييوندها توسط مؤلفة هموارى مشخص مىشود). يس از آنكه كراف را با اين مشخصات ايجاد كرديم،

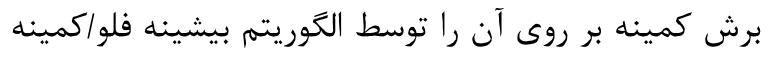
برش بلهدست مى آوريم. بلهدست آوردن اين برش كمينه معادل با بِيداكردن مقدار

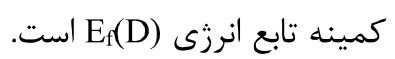

يس از آنكه اين فرآيند X

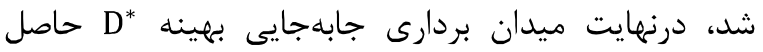

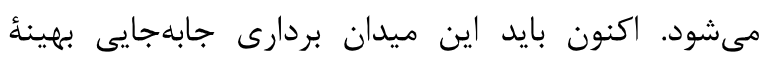

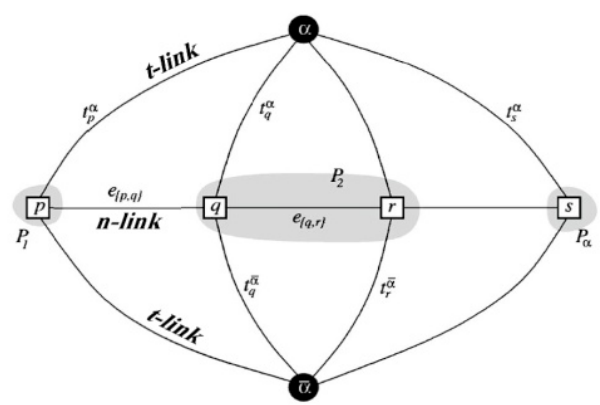

(شكل -ه): نمونهاى از گراف براى يك تصوير يك بعدى. مجموعه ييكسل ها در تصوير عبارت است از

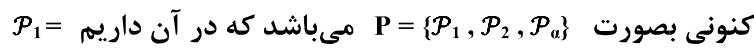

$$
\text { . } \mathcal{P}_{a}=\{s\}, \mathcal{P}_{2}=\{q, r\} \cdot\{p\}
$$

(Figure-5): An example of a graph for a 1D image. The set of pixels in the image is $\mathcal{P}=\{p, q, r, s\}$ and the current partition is $\mathbf{P}=\left\{\mathcal{P}_{1}, \mathcal{P}_{2}, \mathcal{P}_{a}\right\}$, where $\mathcal{P}_{1}=\{p\}, \mathcal{P}_{2}=\{q, r\}$ and $\mathcal{P}_{a}=\{s\}$

بِ إز آنكه كراف را با اين مشخصات ايجاد كرديم، برش كمينه بر روى آن را توسط الكوريتم بيشينه فلواكمينه إنها كردينه برش Boykov و Kolmogorov [16] بهدست مى آوريه. بمدست آوردن اين برش كمينه معادل با بيداكردن مقدار كمينه تابع انرزى

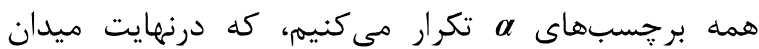

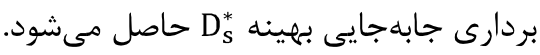
اكنون بايد اين ميدان بردارى جابهجايى بهاينه

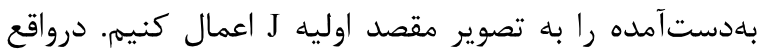

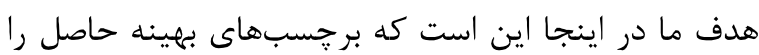

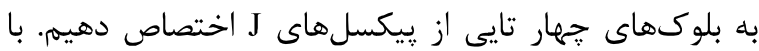

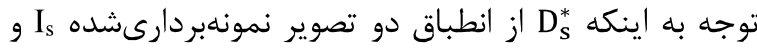

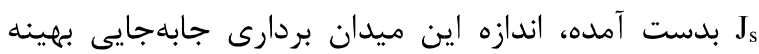
برابر با

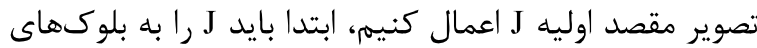

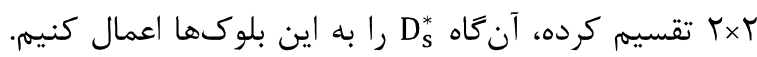

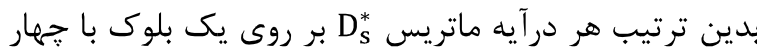

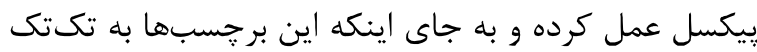

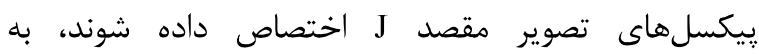

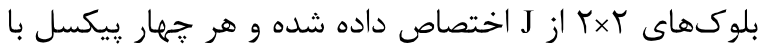
هم جابهجا مىشوند. آنجه در اين مرحله حاصل مىشوده،

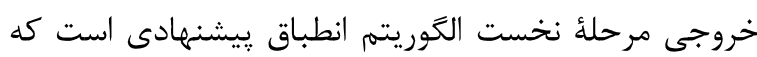

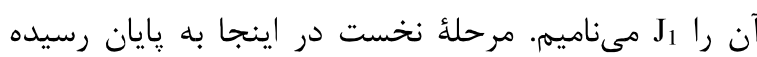

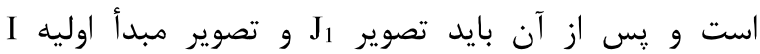
بهعنوان ورودى وارد مرحله دوم الكوريتم شوند. مرحله دوم الكوريتهم انطباق ييشنههادى

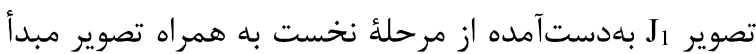
اوليه I ، بهعنوان ورودى به مرحله دوم الكوريتم انطباق 
مشخص كرديم، با اجراى الكوريتم ييشنهادى بهازاى تكتك

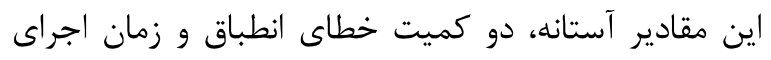
الكوريته را براى هر كدام از اين آستانهها محاسبه كرده و

$$
\text { تابعى بلصورت زير تشكيل مىدهيم: }
$$

$\mathrm{F}=\mathrm{a}_{1}$ RunTime $+\mathrm{a}_{2}$ Error

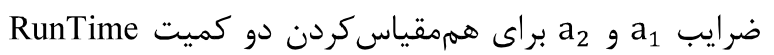

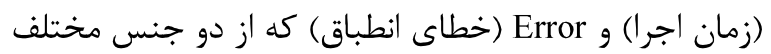

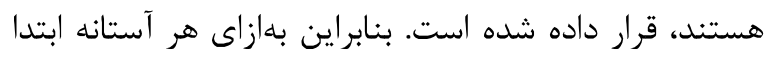

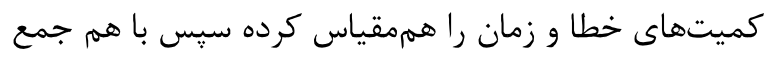
كرده تا مقدار تابع F بهازاى آن آستانه بهدست آيد. در

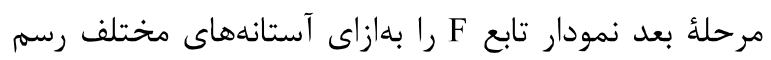

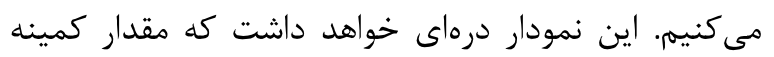

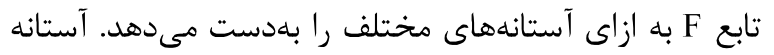

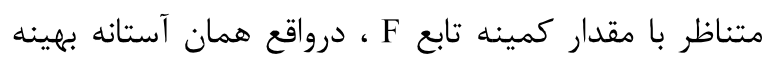

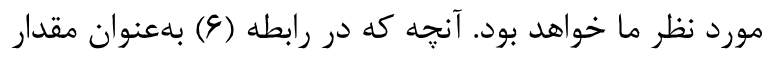
خطا در نظر مى گيريم، مقدار معكوس معيار PSNR است.

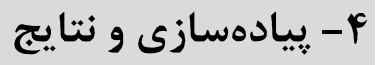

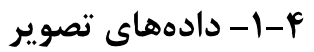

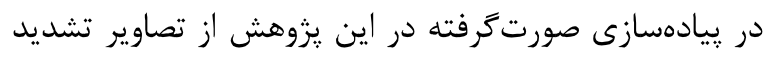

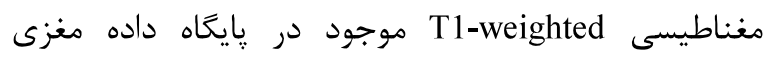
شبيهسازىشده [10] استفاده شده است.

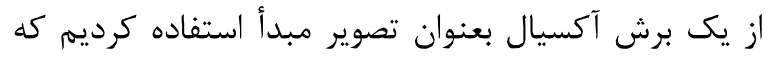
در شكل (r) نشان داده شده است. با ايجاد پينج نوع تغيير

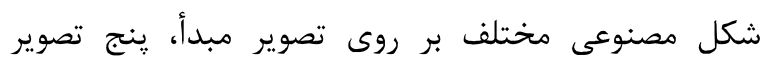

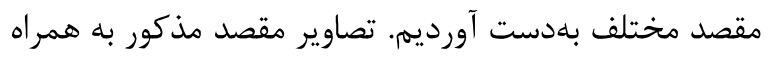

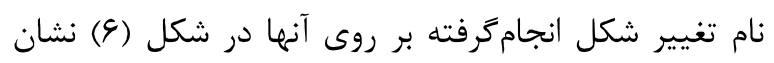

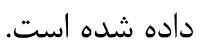

اين تغييرشكلهاى مصنوعى را مىتوان مشابه با

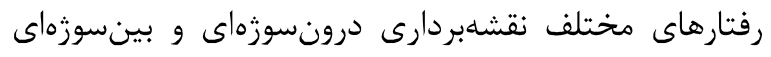

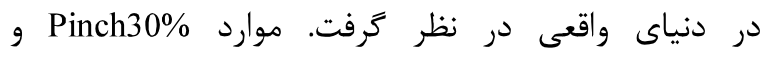
Spherize30\% بطنَ در ميان افراد مختلف يا سنين مختلف، همجزنين بيانكر اثر ساختارى تومورها بر روى بافتهاى مغزى هستند.

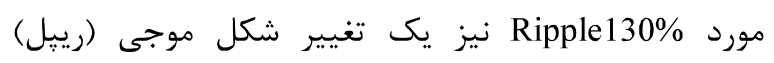

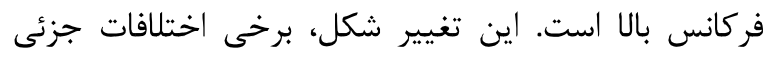

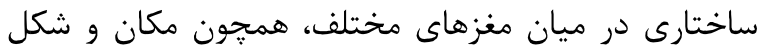
gyri ، sulci

${ }^{2}$ Ventricle
بهدستآمده را به تصوير J1 (خروجى مرحلة نخست) اعمال

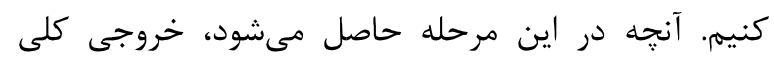
الكوريتم انطباق بيشنهادى است.

در مقايسه با تصوير حاصل از انطباق توسط

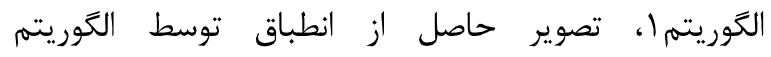

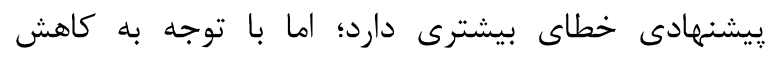
جشمَيرى كه الكَوريتم ويشنهادى در زمان انجام فرآيند انطباق ايجاد مى كند، اين مقدار افزايش خطا قابل قبول

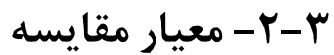

معيارهاى مقايسه در انطباق تصوير بلمنظور ارزيابى نتايج ماسه

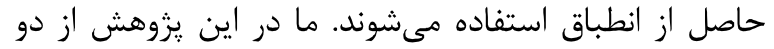

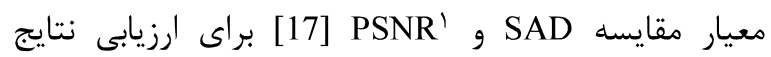

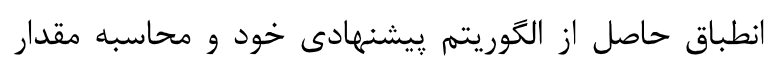

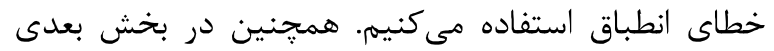

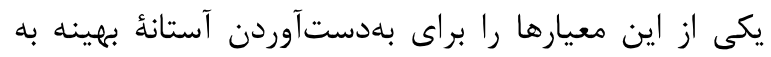
كار خواهيم برد.

\section{r-r- انتخاب آستانه بهينه}

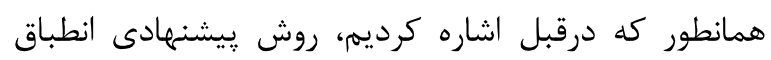

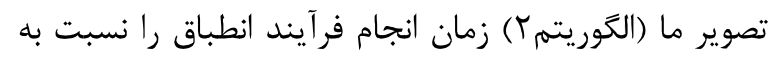

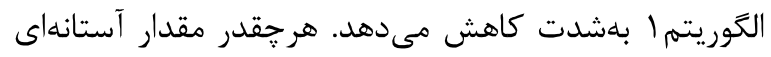

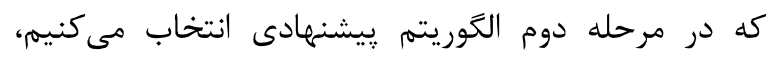

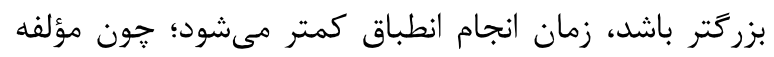
داده متناظر با بيكسل هاى بيشترى صفر شده و كمينهسازى إنى

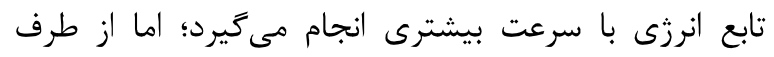
ديكر با زيادشدن مقدار آستانه، همزمان با كاهش زمان لمان اجراى الكَوريتم، خطاى انطباق نيز افزايش مى ئابد. بنابراين

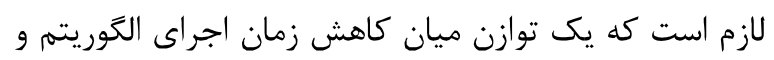

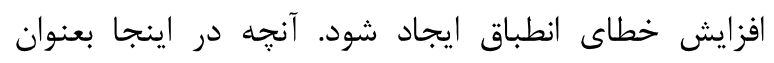

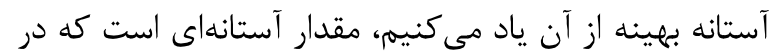

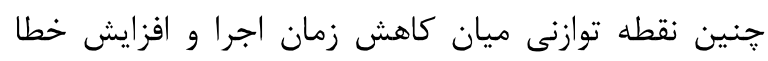
واقع شده باشد. براى بلهدست آوردن مقدار آستانه بهينه ابتدان آندا

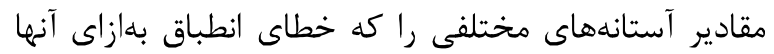
قابل قبول است، مشخص كرده و سيس مقدار آستانٔ بهينه

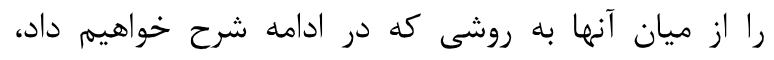

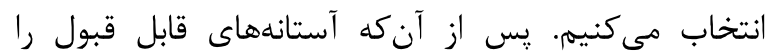

\footnotetext{
${ }^{1}$ Peak-signal-to-noise ratio
} 


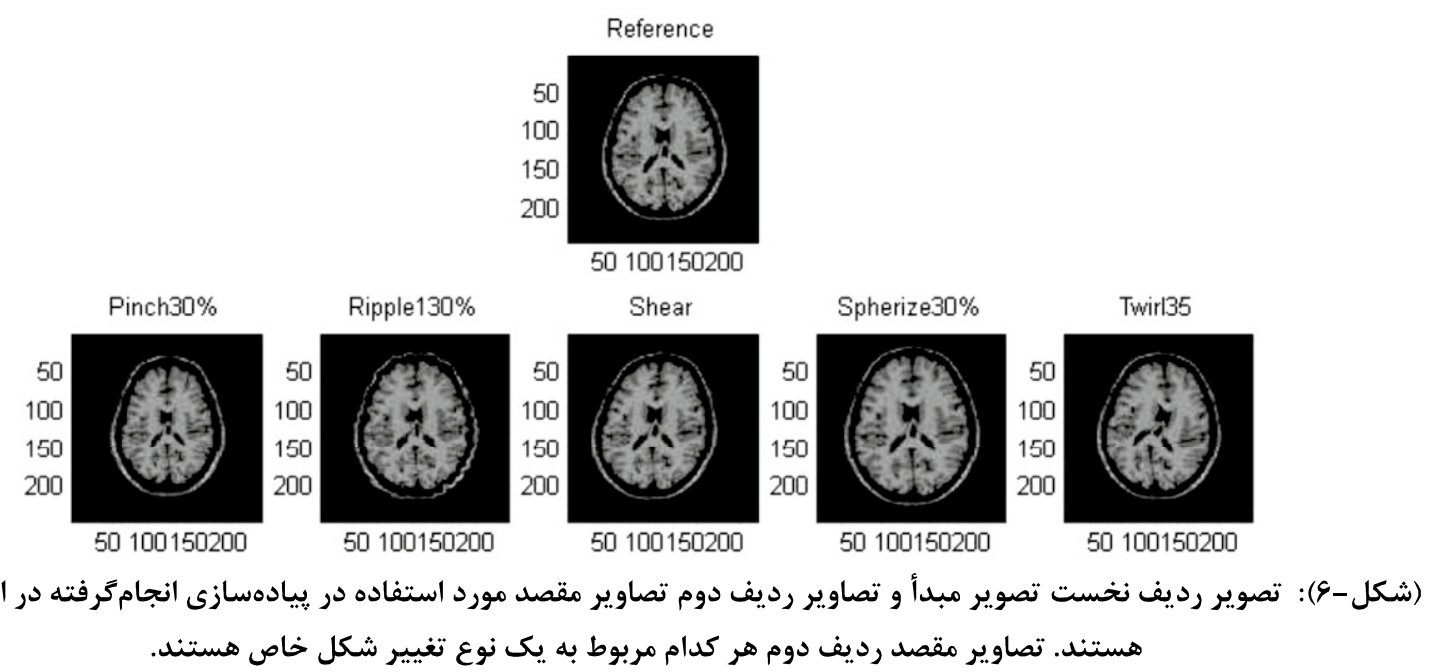

(شكل-\&): تصوير رديف نخست تصوير مبدأ و تصاوير رديف دوم تصاوير مقصد مورد استفاده در رييادهسازى انجامكرفته در اين ثزوهش

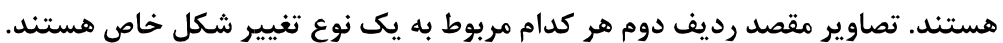

(Figure-6): The first row shows the source image and the second row shows the floating images used in the implementation. Each floating image is related to an especial kind of deformation.

در زيادهسازى الكوريته نيز براى ايجاد تابع انرزى از

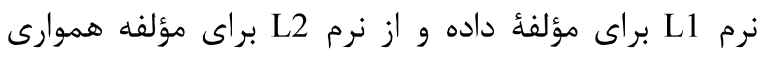

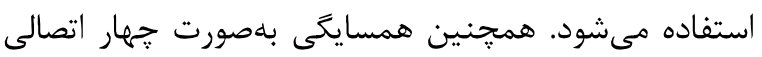

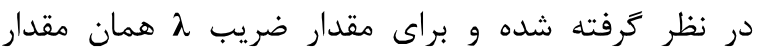

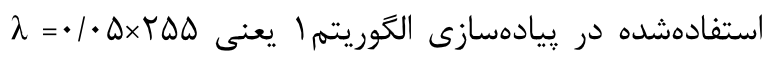

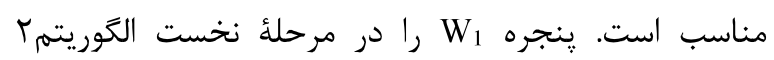
بلهورت W بنابر اين با استفاده از رنجره

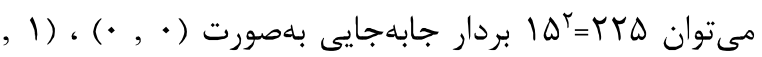

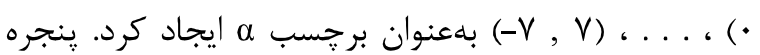

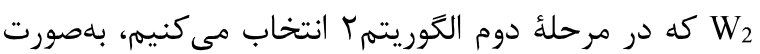

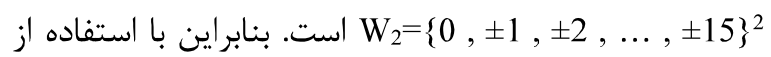

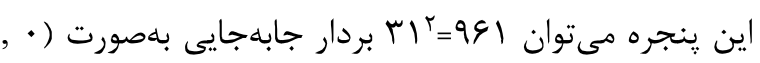

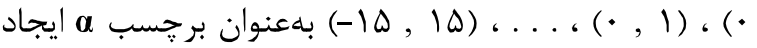

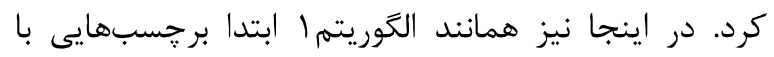

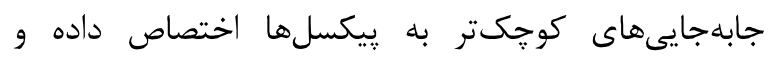

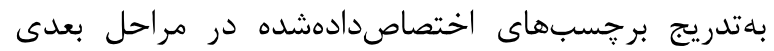
جابجايىهاى بزرگترى دارند. در پيادهسازى الكَوريتهم،

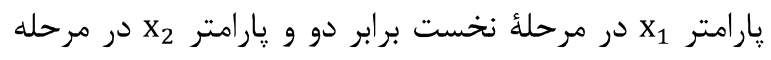
دوم برابر يك در نظر كرفته مىشود. يارامترهاى درواقع همان تعداد دفعات كسترش آلفا هستند. r-r- نتايج در اين بخش ابتدا الكَوريتهم اصلى (الكوريتم|) را بر روى هر

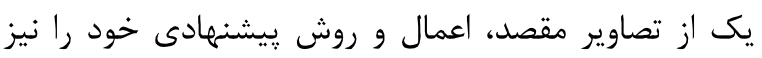
بهازاى آستانههاى قابل قبول، براى هر يك از از تصاوير مقصد

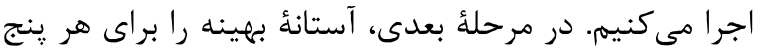
تصوير مقصد به روشى كه در بخش ب-r توضيح داديم،

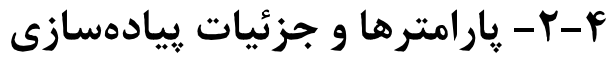

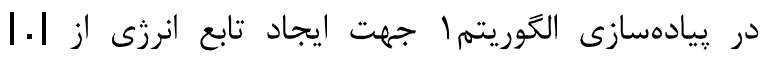

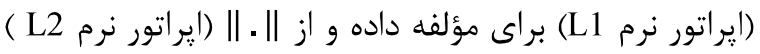
براى مؤلفه هموارى، همان كونه كه در رابطه (سا) آمده،

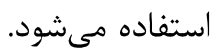
همانطوركه درقبل هم اشاره كرديم، اين توابع داراى

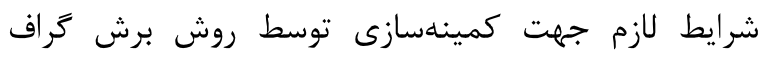

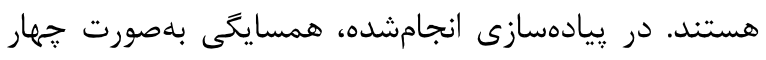

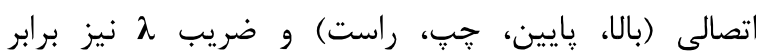

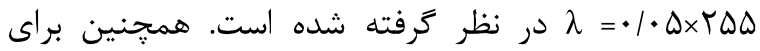

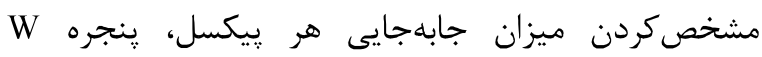

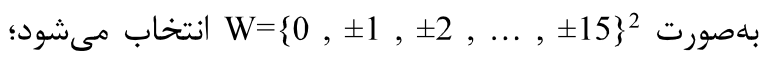
بلهورى كه D(x) موجود در رابطهُ (r) متعلق به اين ينجره

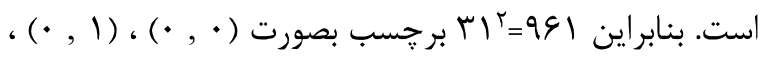

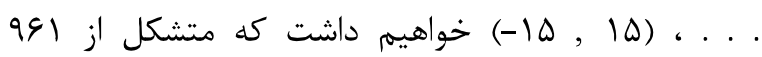
زوجمرتب ايجادشده از اعداد موجود در ينجره W است. درواقع هر برجسب (زوج مرتب) يك بردار جابهجايى دوبعدى إندي

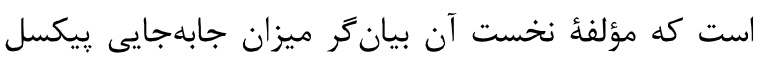

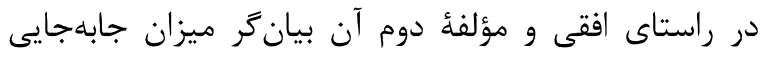
ييكسل در راستاى عمودى خواهد بود. آنجه در الكوريتهم

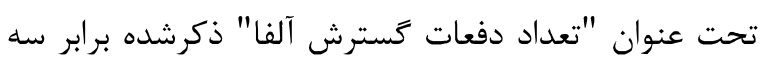
در نظر كرفته شده است. درواقع فرآيند كسترش آنداد دآ آلفا هر

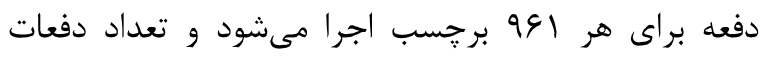

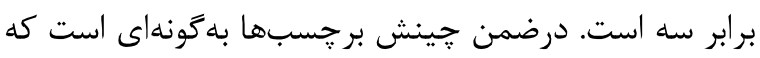

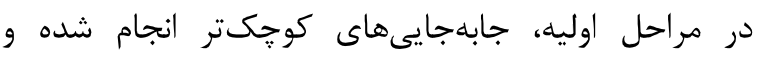
بهتدريج در مراحل بعدى مقدار جابهجايىها بزركتر خواهد 
a مناسب را براى همممقياس كردن اين كميتها بهصورت 10 و a a

نمودار F بعازاى ده مقدار آستانه براى نتايج حاصل از انطباق هر رينج تصوير مقصد ترسيم شده و بدينوسيله مقادير آستانه بهينه براى هر هنج تصوير مقصد از اين نمودارها استخراج و در جدول (1) آورده شده است. در شكل Shear مربوط به تصاوير مقصد Twirl35 و نمودارهاى (V) براى نمونه آمده است.

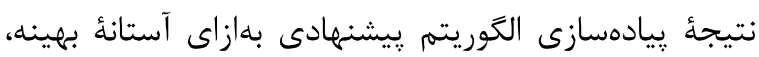

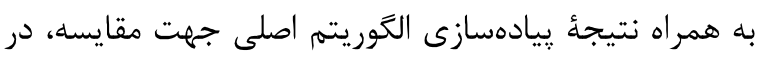
شكل (1) آورده شده است.

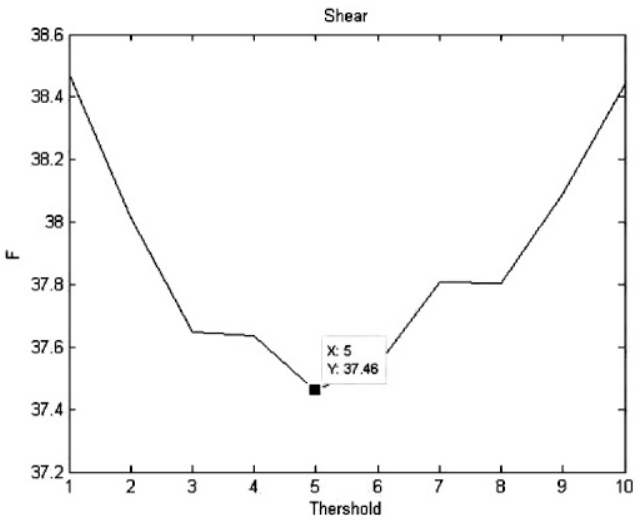

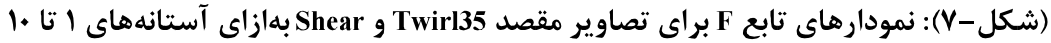

(Figure-7): F function diagrams for threshold values of 1 to 10, for "Shear" and "Twirl35" floating images.
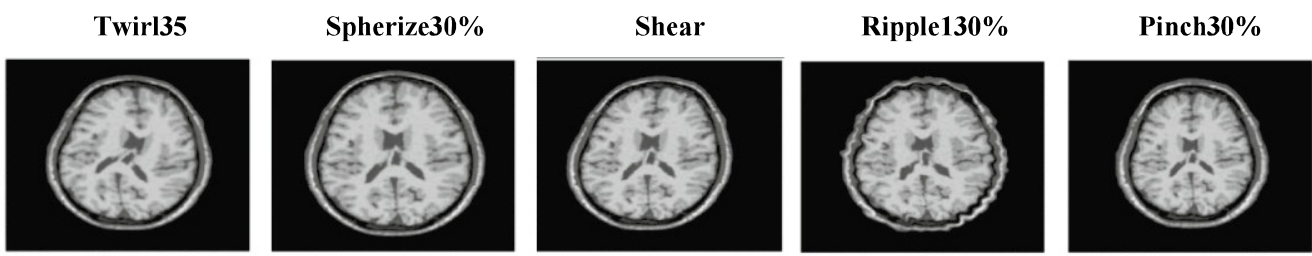

تصاوير مقصد
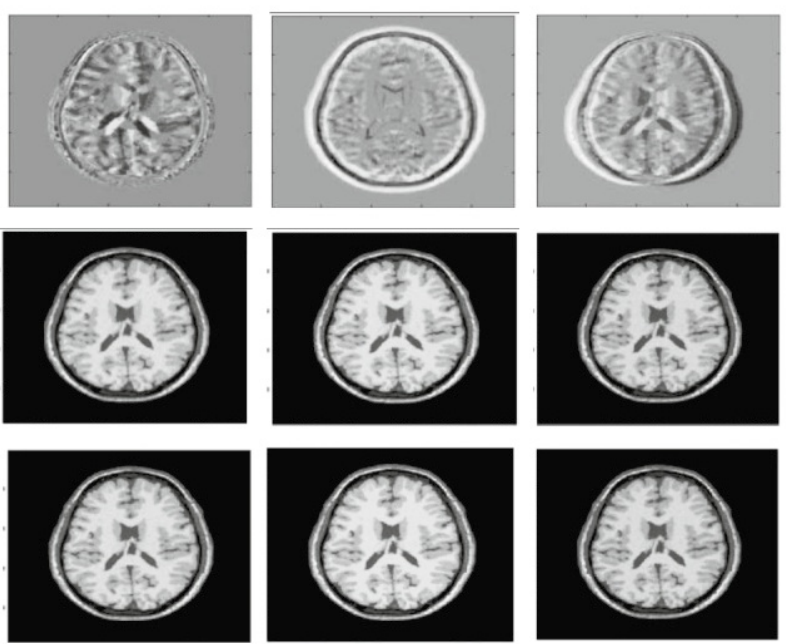

بهدست آورده و به مقايسه نتايج انطباق توسط الثوريتهم ا با نتايج انطباق توسط الخوريتهم (روش بيشنهادى) بهازاى آستانه بهينه، خواهيهم يرداخت. اين مقايسه در غالب تصاوير

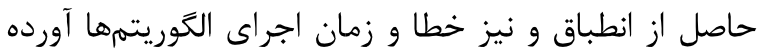
شده است.

براى بلهدستآوردن آستانه بهينه، آستانههاى قابل قبول را مقادير صحيح يك تا ده انتخاب مى كنيم؛ سيس تابع

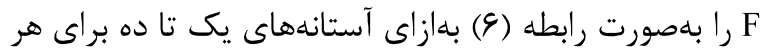
يك از تصاوير تشكيل مىدهيم. همانطور كه درقبل اشاره كرديم، كميت خطا در تابع F را مقدار معكوس معيار PSNR در نظر مى گيريم. با توجه به مقادير كميتهاى RunTime و a بهدست آمده براى تصاوير مختلف، ضرايب a

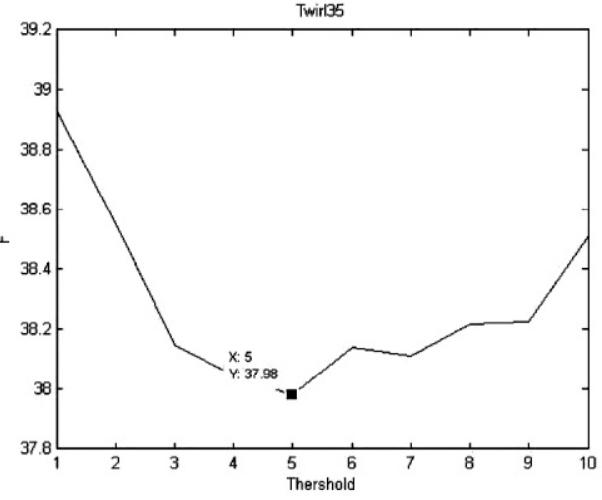

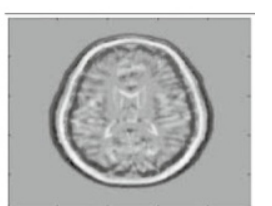

اختلاف قبل از ازباق انطباق
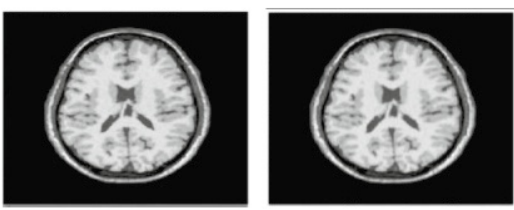

نتيجه انطباق

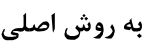
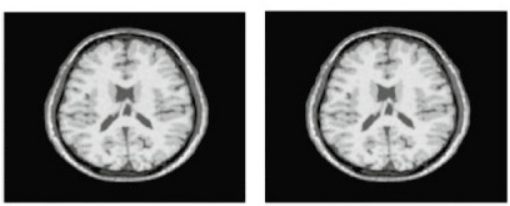

نتيجه انطباق

به به روش بيشنهادى 

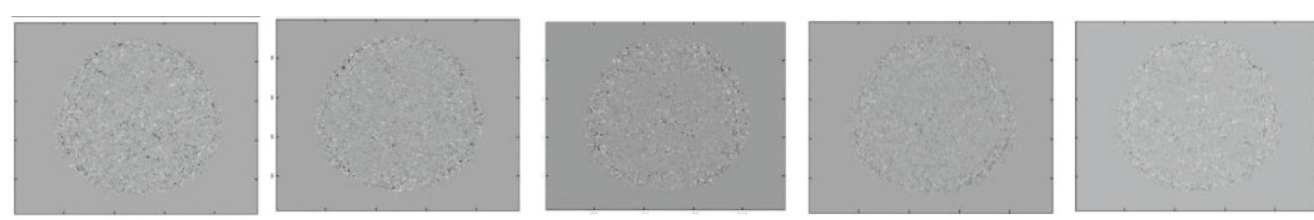

اختلاف بعد از

انطباق

به روش اصلى لي
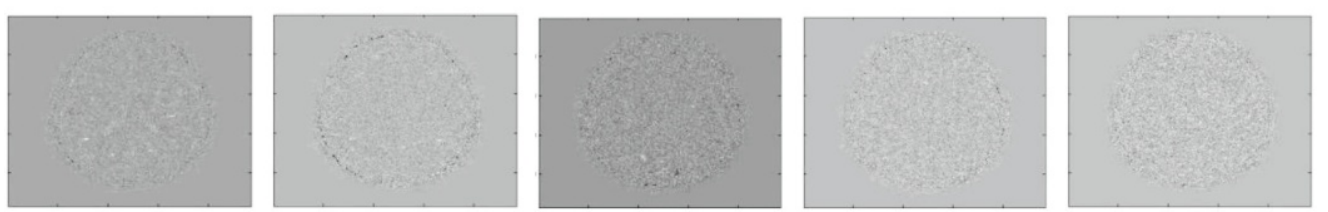

اختلاف بعد از

انطباق

به روش اله

ييشنهادى

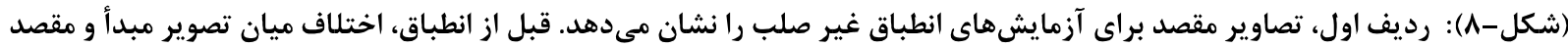

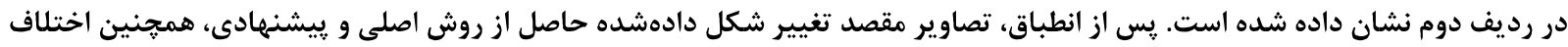

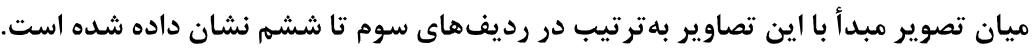

(Figure-8): The first row shows the floating images for the non-rigid registration experiments. Before registration, the differences between the source image and the floating images are shown in the second row. After registration, deformed floating images obtained by using the existing method and the proposed method, as well as the differences between the source image and these deformed floating images are shown in the third to sixth rows, respectively.

انطباق به قيمت اندكى افزايش خطا در نتيجه حاصل از

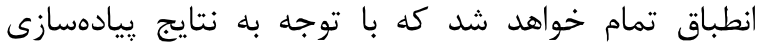

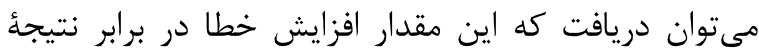

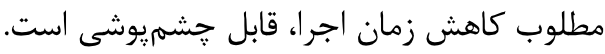

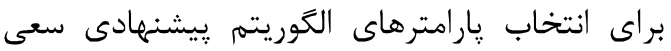

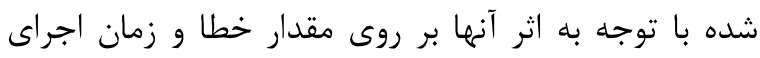

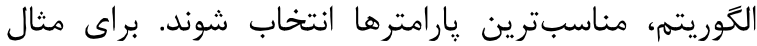

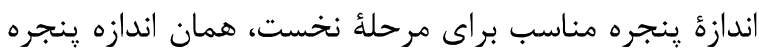

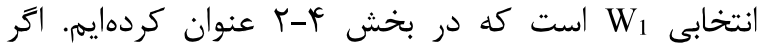

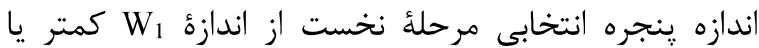
بيشتر باشد باعث افزايش (يا عدم كاهش جشهم إنير) در زمان اجراى الخوريته يا افزايش خطا و يا هر دوى دئن اين موارد خواهد شد.
مقادير معيارهاى مقايسه SAD و PSNR ، همجنين زمان اجراى الكوريتهم، براى دو الكوريتهم ييشنهارهادى (بهازاى آستانه بهينه) و اصلى در جدول (1) با هم مقايسه شدهاند. مقادير آستانه بهينه براى هر ينج تصوير مقصد نيز در اين جدول جدول آورده شده است.

\section{ه- نتيجه گَيرى و بحث}

در اين يزوهش روشى براى انطباق غير صلب تصاوير با برش

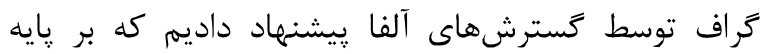
الكوريتم اصلى انطباق بوسيله برش گراف است. ما با ايجاد

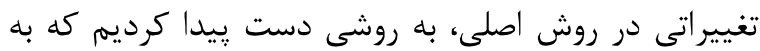

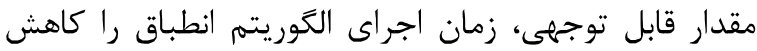
مىدهد. البته اين كاهش قابل توجه در زمان زمان انجام فرآيند

(جدول - (): زمان اجراى الكوريتم و مقادير معيارهاى مقايسه SAD و PSNR، براى دو الكوريته بيشنهادى (به ازاى آستانه بهينه) و اصلى : (Table-1): The run time, SAD value and PSNR value for the proposed algorithm (for optimal threshold) and the existing algorithm.

\begin{tabular}{|c|c|c|c|c|c|c|c|}
\hline \multirow{2}{*}{ مقهدار } & \multicolumn{3}{|c|}{ الكوريته بيشنهادى به ازاى } & \multicolumn{3}{|c|}{ الكوريتم اصلى } & \multirow{2}{*}{ نام تصوير مقصد } \\
\hline & $\begin{array}{c}\text { معيار } \\
\text { PSNR }\end{array}$ & $\begin{array}{l}\text { معيار } \\
\text { SAD }\end{array}$ & زمان اجرا & $\begin{array}{c}\text { معيار } \\
\text { PSNRR }\end{array}$ & $\begin{array}{l}\text { معيار } \\
\text { SAD }\end{array}$ & زمان اجرا & \\
\hline 6 & 42.1930 & 1.0653 & 8.12 & 43.8535 & 0.6153 & 25.16 & Pinch30\% \\
\hline 5 & 42.8082 & 0.9907 & 8.29 & 42.2858 & 0.7623 & 24.96 & Ripple130\% \\
\hline 5 & 42.5928 & 1.0023 & 9.06 & 45.0857 & 0.4819 & 26.09 & Shear \\
\hline 4 & 42.7702 & 0.9518 & 9.47 & 42.7849 & 0.7156 & 25.30 & Spherize $30 \%$ \\
\hline 5 & 42.0183 & 1.0403 & 9.24 & 41.3384 & 0.8848 & 25.49 & Twirl35 \\
\hline
\end{tabular}


[4] J. Kim, J. Fisher, A. Tsai, C. Wible, A. Willsky, and W. Wells, "Incorporating Spatial Priors into an Information Theoretic Approach for FMRI Data Analysis," in Proc. Medical Image Computing and Computer-Assisted Intervention, 2000, pp. 62-71.

[5] K. Nakagomi, A. Shimizu, H. Kobatake, M. Yakami, K. Fujimoto and K. Togashi, "Multishape graph cuts with neighbor prior constraints and its application to lung segmentation from a chest CT volume," Medical Image Analysis, vol. 17 (1), pp. 62-77, 2013.

[6] Ch. Ballangan, X. Wang, M. Fulham, S. Eberl, and D. Feng, "Lung tumor segmentation in PET images using graph cuts," Computer Methods and Programs in Biomedicine, vol. 109 (3), pp. 260-268, 2013.

[7] A.A. Meneses, A. Giusti, A.P. de Almeida, L. Nogueira, D. Braz, C.E. de Almeida and R.C. Barroso, "Segmentation of Synchrotron Radiation micro-Computed Tomography Images using Energy Minimization via Graph Cuts," Applied Radiation and Isotopes, vol. 70 (7), pp. 1284-1287, 2012.

[8] R.W.K. So and A.C.S. Chung, "Multi-level nonrigid image registration using graph-cuts," in IEEE International Conference on Acoustics, Speech and Signal Processing, 2009, pp. $397-$ 400.

[9] R.W.K. So and A.C.S. Chung, "Non-rigid image registration by using graph-cuts with mutual information," in 17th IEEE International Conference on Image Processing (ICIP), 2010, pp. 4429-4432.

[10] R.W.K. So, T.W.H. Tang and A.C.S. Chung "Non-rigid image registration of brain magnetic resonance images using graph-cuts," Pattern Recognition, vol. 44 (10-11), pp. 2450-2467, 2011.

[11] S. Liao and A.C.S. Chung, "Nonrigid Brain MR Image Registration using Uniform Spherical Region Descriptor," IEEE Transactions on Image Processing, vol. 21 (1), pp. 157-169, 2012.

[12] D. Mahapatra and Y. Sun, "Integrating Segmentation Information for Improved MRFBased Elastic Image Registration," IEEE Transactions on Image Processing, vol. 21 (1), pp. 170-183, 2012.

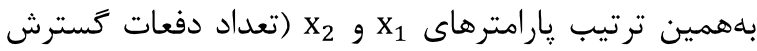

$$
\begin{aligned}
& \text { آلفا بهترتيب در مرحلئ نخست و دوم) را بهَّونهاى انتخاب } \\
& \text { كرديم كه كمترين افزايش در مقدار خطا و بيشترين كاهش }
\end{aligned}
$$

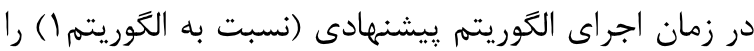

$$
\begin{aligned}
& \text { در خروجى نهايى نتيجه دهد. } \\
& \text { براى انجام مطالعات و كارهاى آينده در زمينههاى تئن } \\
& \text { مرتبط با كار انجامشده در اين يزوهش مى دئوان به انهات انطباق } \\
& \text { تصاوير سهبعدى اشاره كرد. براى موارد انطباق تصاوير } \\
& \text { سهبعدى به روش برش كراف بايد كرافى با اندازه تصوير }
\end{aligned}
$$

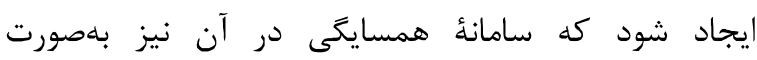

$$
\begin{aligned}
& \text { ششاتصالى تعريف مىشود. در جنين حالتى مىتوان تصور } \\
& \text { كرد كه فضاى راهحلهاى موجود جقدر بزرى خواهي }
\end{aligned}
$$

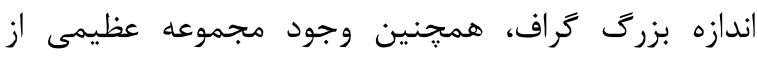

$$
\begin{aligned}
& \text { برجسبها درنهايت باعث افزايش هر جه جه بيشتر زمان } \\
& \text { محاسباتى اين روش خواهد شد كه استفاده از آن را براى داى برائران } \\
& \text { كاربردهاى يزشكى در محيطهاى بالينى متداول دشوار }
\end{aligned}
$$

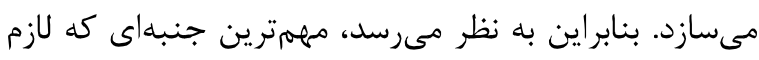

$$
\begin{aligned}
& \text { است در مطالعات آينده مورد توجه قرار تيرد، تمركز بر روى }
\end{aligned}
$$

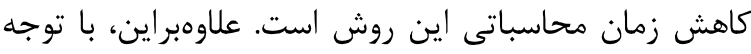

$$
\begin{aligned}
& \text { به اينكه فرمولبندىاى كه در اين يزوهش براى درائ حل مسئله }
\end{aligned}
$$

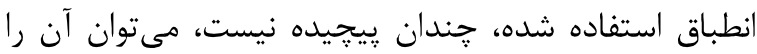

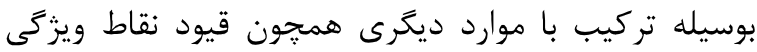

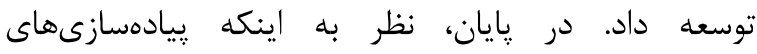

$$
\begin{aligned}
& \text { انجامكرفته در اين يزوهش بر روى تصاوير تشديد مغناطيسى دئي } \\
& \text { مغز انجام شده است، بهطور نظرى امكان بيادهسازى روش }
\end{aligned}
$$

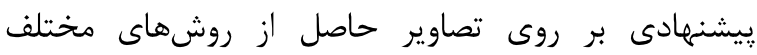

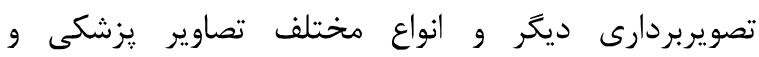

$$
\begin{aligned}
& \text { كاربردهاى ديكر نيز وجود دارد. }
\end{aligned}
$$

\section{6-Refrences}

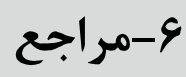

[1] D. Ruckert, L.I. Sonoda, C. Hayes, D.L.G. Hill , M.O. Leach and D.J. Hawkes, "Non rigid registration using free form deformations: Application to breast MR images," IEEE transactions on Medical imaging, vol. 18 (8), pp. 712-721, 1999.

[2] J. B. Antoine Maintz and Max A. Viergever, "A Survey of Medical Image Registration," Medical Image Analysis, vol. 2 (1), pp. 1-36, 1998.

[3] A. Sotiras and N. Paragios, "Deformable Image Registration: A Survey," in INRIA Research Report $n^{\circ}$ 7919, Ecole Centrale de Paris, 2012. 


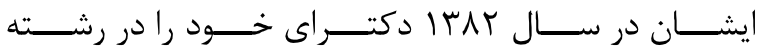

$$
\begin{aligned}
& \text { مهندسـى يزشـكى در دانشـعاه تهــران بــه اتمسام رسـاند. }
\end{aligned}
$$

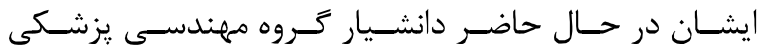

$$
\begin{aligned}
& \text { دانشـكده مهندسـى بـرق دانشــاه صــعتى شـريف بــوده و }
\end{aligned}
$$

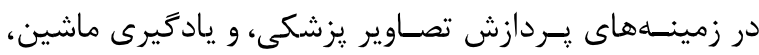

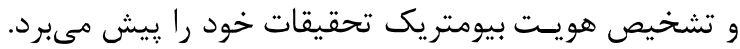

$$
\begin{aligned}
& \text { نشانى رايانامه ايشان عبارت است از: }
\end{aligned}
$$

\section{fatemizadeh@sharif.edu}

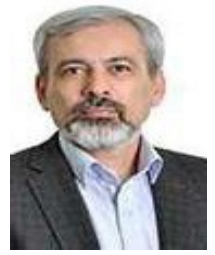

$$
\begin{aligned}
& \text { حميد بهنــام مـدرى كارشناسـى خــود } \\
& \text { را در رشـته الكترونيـك از دانشـعاه علـهم }
\end{aligned}
$$

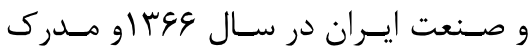

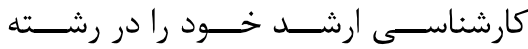

مهندسـى زيزشـكى از دانشــاه صــنعتى شــريف در ســال

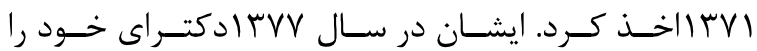
در رشـته الكترونيـى كـاربردى در دانشـعاه صسنعتى توكيسو بــه اتمــام رســاند. ايشــان در حــال حاضــر دانشـيار خـروه

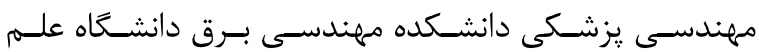

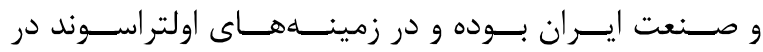

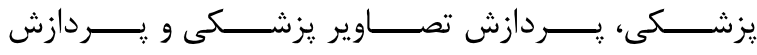

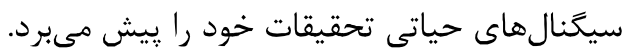

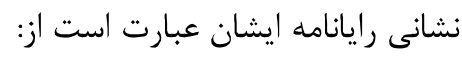

behnam@iust.a
[13] H. Lombaert and F. Cheriet, "Simultaneous image de-noising and registration using graph cuts: Application to corrupted medical images," in 11th International Conference on Information Science, Signal Processing and their Applications (ISSPA), 2012, pp. 264-268.

[14] J. Michalek and M. Capek, "A Piecewise Monotone Subgradient Algorithm for Accurate $\mathrm{L}^{1}$-TV Based Registration of Physical Slices With Discontinuities in Microscopy," IEEE Transactions on Medical Imaging, vol. 32 (5), pp. 901-918, 2013.

[15] V. Kolmogorov and R. Zabih, "What energy functions can be minimized via graph cuts?," IEEE Transactions on Pattern Analysis and Machine Intelligence, vol. 26 (2), pp. 147-159, 2004.

[16] Y. Boykov and V. Kolmogorov, "An Experimental Comparison of Min-Cut/MaxFlow Algorithms for Energy Minimization in Vision," IEEE Transactions on Pattern Analysis and Machine Intelligence, vol. 26 (9), pp. 1124 $-1137,2004$

[17] A. Horé and D. Ziou, "Image Quality Metrics: PSNR vs. SSIM," in 20th International Conference on Pattern Recognition (ICPR), 2010, pp. 2366-2369.

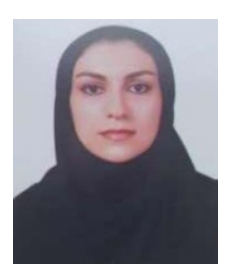

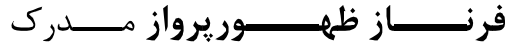

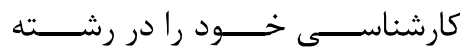

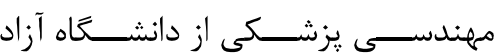

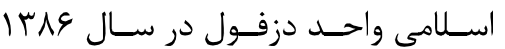

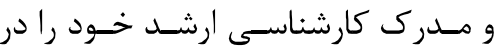

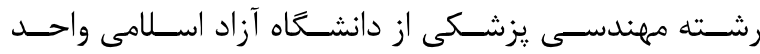
علـوم و تحقيقـات تهــران در سـال اوسا اخــذ و در حهـال

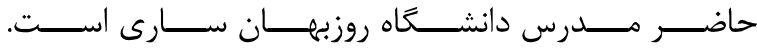

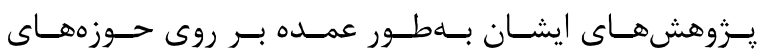
يردازش تصوير و سيگنال متمركز است. نشانى رايانامه ايشان عبارت است ازئ

\section{fzohourparvaz@gmail.com}

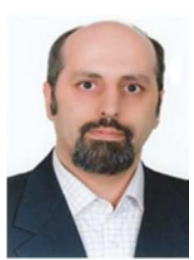

$$
\begin{aligned}
& \text { عمــــاد الـــدين فــــاطمى زاده مــدرى } \\
& \text { كارشناسـى خــود را در رشـته الكترونيـك }
\end{aligned}
$$

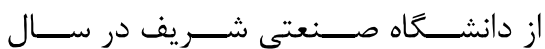

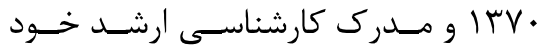

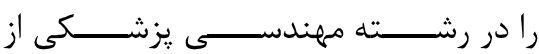

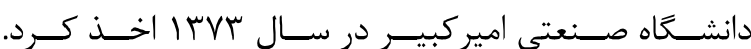

